\title{
A survey of the past earthquakes in the Eastern Adriatic (14th to early 19th century)
}

\author{
Paola Albini \\ Istituto Nazionale di Geofisica e Vulcanologia, Sezione di Milano, Italy
}

\begin{abstract}
Focusing on the Eastern Adriatic region, from Zadar in the north to Corfu in the south, the background information supporting our knowledge of the seismicity in the time-span 14th to early 19th century is discussed from the point of view of the historical earthquake records. The late 19th century seismological compilations turn out to be those responsible for the uneven spatial and temporal distribution of seismicity suggested by current parametric earthquake catalogues. This awareness asked for a comprehensive reappraisal of the reliability and completeness of the available historical earthquake records. This task was addressed by retrieving in the original version the information already known, by putting the records in the historical context in which they were produced, and finally by sampling historical sources so far not considered. Selected case histories have been presented in some detail also. This material altogether has shown that i) current parameterisation of past earthquakes in the Eastern Adriatic should be reconsidered in the light of a critically revised interpretation of the available records; ii) collecting new evidence in sources and repositories, not fully exploited so far, is needed. This should aim mostly at overcoming another limitation affecting the evaluation of full sets of earthquake parameters, that is the few observations available for each earthquake. In this perspective, an optimistic assessment of the potential documentation on this area is proposed.
\end{abstract}

Key words Eastern Adriatic - historical earthquakes

\section{Introduction}

Despite the efforts of many researchers dating back to the UNESCO project in early seventies (Shebalin, 1974; Shebalin et al., 1974), the seismicity of the Balkan area is still poorly known. This contribution focuses on Eastern Adriatic from Zadar (Croatia) in the north to Corfu (Greece) in the south; it deals mainly with the seismicity of the islands and coastal area of Croa-

Mailing address: Dr. Paola Albini, Istituto Nazionale di Geofisica e Vulcanologia, Sezione di Milano, Via E. Bassini 15, 20133 Milano, Italy; e-mail: albini@mi.ingv.it tia, Bosnia and Herzegovina, Serbia and Montenegro, Albania and Epirus (Greece). A two-fold perspective was chosen, aiming at: i) checking the background knowledge supporting the available earthquake catalogue parameters; ii) analysing spatial and temporal seismicity patterns in relation with the actual distribution of historical observations of earthquake effects.

Since, here as everywhere, geopolitical issues and changes have influenced and shaped the distribution of historical records, the timespan considered is limited to the five hundred years between 14th and early 19th century.

Selected case histories will allow the author to highlight some sub-regional conditions which have determined both production and transmission of historical earthquake records and which still affect the knowledge of the seismicity of the Eastern Adriatic region. Newly retrieved sources 
are used also to propose updated studies of key earthquakes in diverse periods and areas. The comprehensive analysis and the new effect distributions here presented turn out to be material useful to highlight tools and paths towards an improvement of the knowledge of the past seismicity in the Eastern Adriatic.

\section{Seismicity of the Eastern Adriatic according to current parametric catalogues}

The portion of the Balkans here considered is shown in fig. 1 by means of a polygonal outline. For this area, from now on referred to as
Eastern Adriatic, data on major seismicity $\left(I_{0} \geq 7\right)$ up to early 19 th century are contained in five parametric catalogues published between 1974 and 1997 (table I).

A thorough analysis of these catalogues with respect to earthquake parameters has been performed in the frame of the project «A Basic European Earthquake Catalogue and a Database - BEECD» (Albini and Stucchi, 1997; also at http://emidius.mi.ingv.it/BEECD), and will not be repeated here. Each record included in the 1997 «BEECD Working File» was chosen as the «best» among those available from the parametric catalogues. It is worth recalling that among the five parametric catalogues only

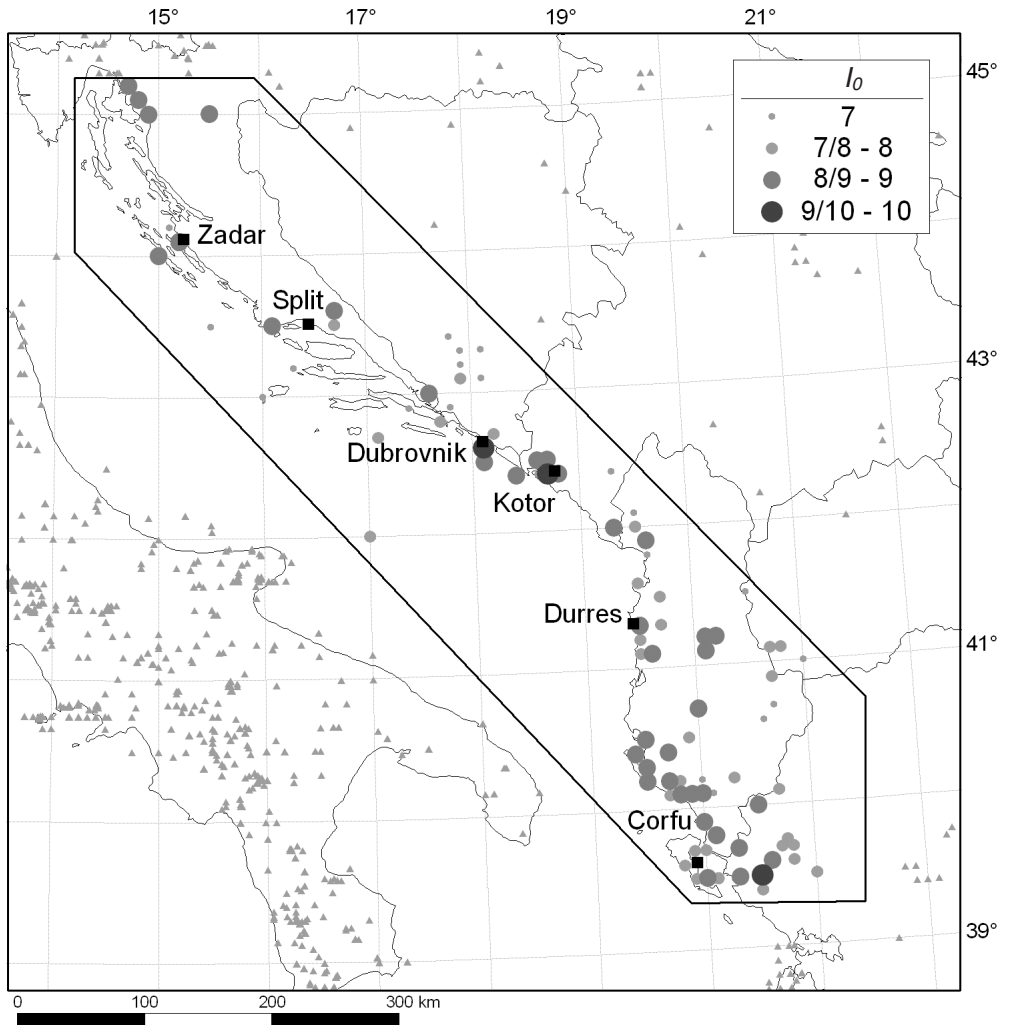

Fig. 1. Eastern Adriatic and its present geopolitical features in the background. The area of interest of this paper is defined by the polygon. Parameters for earthquakes between 1000 and 1899 are taken from the 1997 BEECD Working File and were chosen as the best among those supplied by the main available parametric catalogues for this region (see table I). 
Table I. Time and space coverage of the main catalogues for Eastern Adriatic.

\begin{tabular}{lllccc}
\hline \hline \multicolumn{1}{c}{ Catalogue } & $\begin{array}{c}\text { Time-span of the } \\
\text { whole catalogue }\end{array}$ & $\begin{array}{c}\text { Area or sub-areas } \\
\text { within Eastern } \\
\text { Adriatic }\end{array}$ & $\begin{array}{c}\text { Records in } \\
\text { East. Adr. } \\
1000-1529\end{array}$ & $\begin{array}{c}\text { Records in } \\
\text { East. Adr. } \\
1530-1806\end{array}$ & $\begin{array}{c}\text { Records in } \\
\text { East. Adr. } \\
1807-1899\end{array}$ \\
\hline $\begin{array}{l}\text { Shebalin } \text { et al. (1974) } \\
\begin{array}{l}\text { Herak, 1995 } \\
\text { (unpublished) }\end{array}\end{array}$ & 2100 B.C.-1970 & Eastern Adriatic & 27 & 19 & 106 \\
$\begin{array}{l}\text { Sulstarova and } \\
\text { Kociu (1975) }\end{array}$ & $\begin{array}{l}\text { 3rd century } \\
\text { B.C.-1970 }\end{array}$ & $\begin{array}{l}\text { Eastern Adriatic } \\
\text { Albania and Epirus }\end{array}$ & 28 & 20 & 68 \\
$\begin{array}{l}\text { Papazachos and } \\
\text { Papazachou (1989) }\end{array}$ & 550 B.C.-1986 & $\begin{array}{l}\text { Montenegro, } \\
\text { Albania, Epirus } \\
\text { and Corfu (GR) }\end{array}$ & 1 & 5 & 73 \\
$\begin{array}{l}\text { Papazachos and } \\
\text { Papazachou (1997) }\end{array}$ & & $\begin{array}{l}\text { Montenegro, } \\
\text { Albania, Epirus } \\
\text { and Corfu (GR) }\end{array}$ & 1 & 13 & 26 \\
\hline
\end{tabular}

The last three columns give the amount of records listed by each catalogue with an epicentre within the area of interest according to three time-frames.

Papazachos and Papazachou (1989 and 1997) supply magnitude values. Thus epicentral intensity $\left(I_{0}\right)$ is used instead of magnitude both in text and figures, though this value also does not express homogeneously the size of the catalogued earthquakes. Table I shows chronological and geographical coverage of the catalogues dealing with the Eastern Adriatic.

The last three columns show the distribution, deriving from the catalogues, of the seismicity of the Eastern Adriatic according to three time frames. These three time frames have been chosen primarily according to features of historical significance, especially from the point of view of production and conservation of earthquake records on this area; such geopolitical implications will be highlighted in the following sections. This contribution is focused on the period 1300-1806: this means that it considers 55 earthquakes in all, with an epicentral intensity ranging from 7 to 10 .

From a first crosschecking of data on time and location of earthquakes between the 14th and early 19th century, some features emerge: i) clusters of seismicity in and around Zadar between 1300 and 1400 and in the area of Dubrovnik and Kotor between the early 15 th century and 1667 , when the large $\left(I_{0}=10\right)$ Dubrovnik earthquake occurred; in contrast, ii) few earthquakes are list- ed up to the 15th century for the whole Eastern Adriatic coast (from Split to Corfu, with the exception of Zadar) and from early 17 th century to late 18th century from Zadar to Shkodër (northern Albania).

As a consequence of this preliminary analysis, focus was put on exploring the background of the information as available to compilers of parametric catalogues, to try and understand how and how much the sources of information they used are those responsible for this uneven spatial and temporal distribution of the seismicity in the Eastern Adriatic.

\section{Background to seismic catalogues}

\subsection{Previous catalogues and seismological compilations}

The earthquake catalogues prepared and used in the frame of the UNDP-UNESCO project «Survey of the seismicity of the Balkan region» (1969-1974) still form the bulk of the information background of current parametric catalogues for the Eastern Adriatic (fig. 2).

Apart from Trajic (1961), the others go back to the early seventies (Cvijanovic, 1971, 1972; Basovic, 1973; Sulstarova et al., 1971). They 


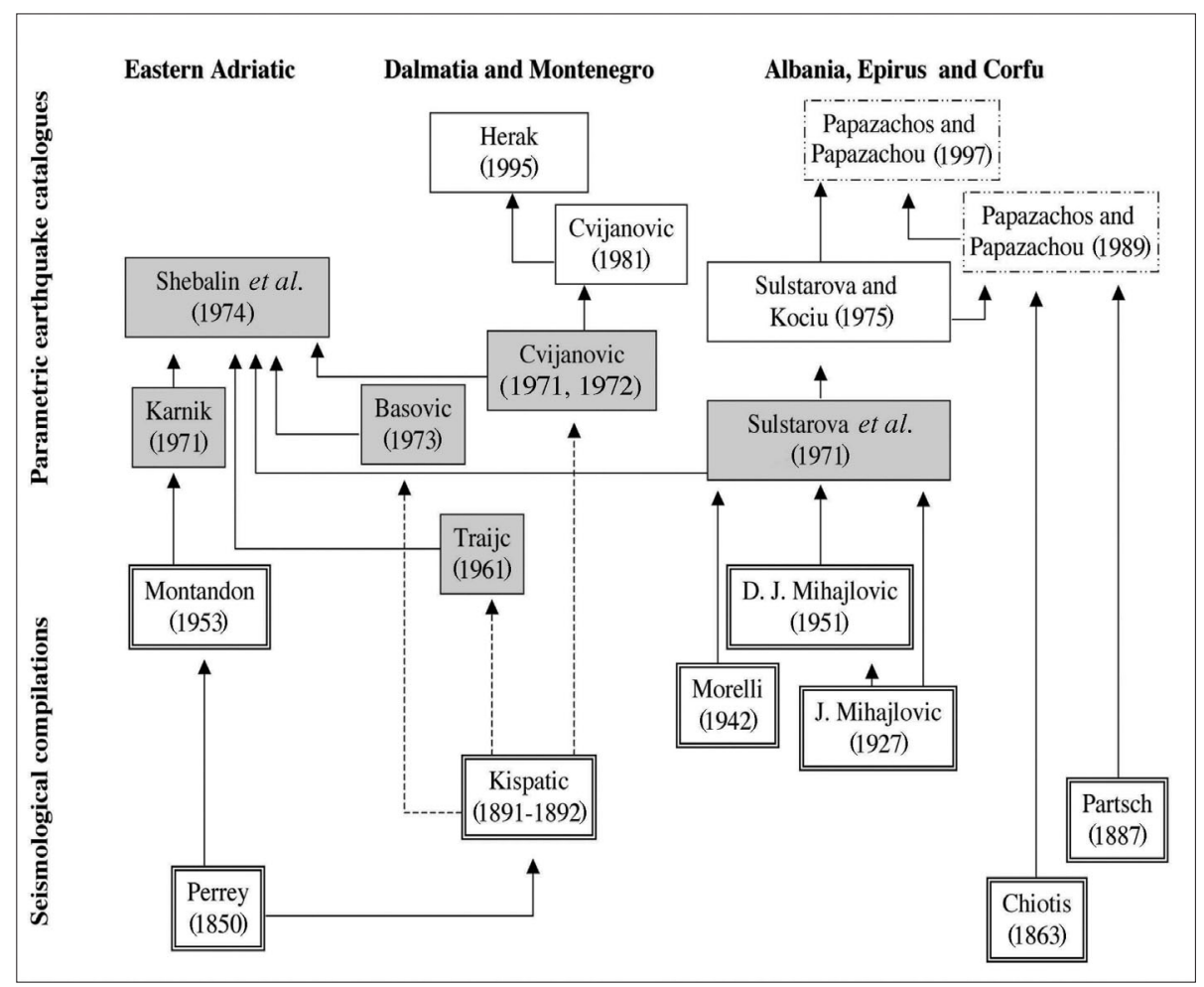

Fig. 2. Background of the parametric earthquake catalogues for Eastern Adriatic. Shaded boxes highlight the catalogues supporting and explicitly mentioned by Shebalin et al. (1974).

were purposely prepared for the publication of the Balkan catalogue (Shebalin et al., 1974) and are described as «manuscripts» in the reference list; in fact they were typewritten lists of earthquake parameters (which could still be seen in V. Karnik's archive at the Seismological Institute of the Academy of Sciences, Prague, in 1996).

As for the rest of Europe and the Mediterranean, the compilation of the parametric catalogues on the Balkan area started from descriptive collections of earthquakes, usually referred to as seismological compilations, spreading since the mid nineteenth century. Apart from those covering Europe, such as the well-known works by Perrey (e.g., 1850) and by Mallet (1853), the main interest in this investigation was to find out those specifically devoted to the Eastern Adriatic.

For historical Dalmatia, that is for territories today in Croatia, Bosnia and Herzegovina, Serbia and Montenegro, the catalogues included in Shebalin et al. (1974) do not explicitly mention their sources of information (fig. 2, dashed connectors). That they were partly derived from the seismological compilation by Kispatic (18911892) had to be inferred by an accurate reading of the text (the original is in Croatian).

J. Mihailovic (1927), Morelli (1942), and D.J. Mihailovic (1951) are specific seismological compilations related to Albania, Epirus and Corfu (Greece) quoted by Sulstarova and Kociu (1975). Concerning mainly Corfu, Chiotis (1863) and Partsch (1887) are the collections of 
earthquake records with the longest time-span used by Papazachos and Papazachou (1989 and 1997).

\subsection{Behind the seismological compilations}

To achieve a good understanding of the background of the parametric catalogues, and define how information on historical earthquakes has flowed into them, an analysis was performed on the set of historical earthquake records, those derived from both primary and second-hand historical sources, used by the seismological compilations for the Eastern Adriatic.

From now on place names will be given either according to today's use only or, preferably, together with the toponym of Italian origin; this depends on the latter being the one mostly used during the time-span considered and by most of the coeval historical sources investigated (see for instance the Documentary Appendix).

Starting from the southernmost part of the study area (Corfu, Greece), Chiotis (1863) collected information from published historical sources, mainly on the Ionian Islands; Partsch (1887), geographer and scientist, concentrated on Corfu, and he mostly used sources that are contemporary to the earthquakes; the limitation of his compilation is its dealing only with earthquakes from 1650 onwards.

For Albania and Epirus (Greece), J. Mihailovic (1927), Morelli (1942) and D.J. Mihailovic (1951) relied upon seismological compilations of late 19th-early 20th century. Though restricted to the Albanian area, these works are not original, in that they mostly derive their information from the classical works of Perrey (1850) and Mallet (1853).

For most of the area investigated, corresponding to historical Dalmatia, from Cattaro/Kotor in the south to Zara/Zadar in the north, the most important collection of earthquake records dates back to the late 19th century and is the work of Miso Kispatic (1891-1892).

A member of the Academy of Sciences at Zagreb, Kispatic introduces reasons and means of his work «Potresi u Hrvatskoj» (Earthquakes in Croatia) at the end of an introduction on the theories of earthquakes and before listing the sources for his «Chronicle». We learn that the material supporting his compilation was collected during fourteen years of investigation and that his main interest was the territory of Croatia at the turn of the 19th century. When Kispatic published his essay, Croatia was an Austrian province, separated from the province of Dalmatia from the administrative point of view. But the historical links were so strong that earthquakes affecting Dalmatia were obviously considered by Kispatic.

In acknowledging his helpers Kispatic mentions their specific contribution in terms of typology of documents and archive or library storing the historical sources. The then most distinguished researchers on the history of Croatia did supply him with primary sources, from medieval chronicles to administrative documents for the Modern Age: worth mentioning are the librarian Ivan Kostrencic, from the University at Zagreb, and the historian Sime Ljubic. The latter was among the editors of a «corpus» of medieval documents on this area and the Balkans in general (Ljubic, 1893); he had also worked at the State Archive of Venice (Ljubic, 18761880) and is the one responsible for the set of Venetian documents quoted and summarised in Kispatic's seismological compilation. Most of the sources concerning Zara were given to Kispatic by Prof. S. Brusina, then working at the Library of Zara.

Retrieving the most significant sources listed in Kispatic's work has meant going back to the same repositories in which the researchers he acknowledges were working at that time.

On the one hand, a direct reading of Kispatic's sources for earthquakes in Eastern Adriatic, without the intermediation of the transcription or summary made by his suppliers, has clearly indicated that the main value of Kispatic's work is represented by the assembling and ordering of a good set of primary and secondary sources.

On the other hand, for a critical use of his data towards a proper and reliable seismological interpretation there is the need to go back to 
the original sources, put them in their historical context, but mainly to look for additional, fundamental information which can put the earthquake records in a correct perspective.

Kispatic did not read directly the sources he quotes, and this indirect and very partial knowledge is the reason for a sort of uncritical and indiscriminate acceptance of all the pieces of information on earthquake effects his collaborators were supplying him with. Nor did he perform or ask for a comprehensive investigation on the historical sources for Dalmatia.

The most evident gaps in terms of repositories not investigated are:

i) the Archive of Ragusa/Dubrovnik: it was not considered and no documents produced by the independent Republic of Ragusa are mentioned;

ii) the Archive of Zara/Zadar, ruled by and seat of the Venetian governors through the centuries (1208-1358 and 1409-1797) was not investigated; Kispatic's sources on Zadar are mostly printed sources (19th century local histories), and some manuscripts, mainly for 18th century earthquakes;

iii) the State Archive of Venice: Venetian documents are in fact used by Kispatic, but their use is restricted to some major earthquakes and to some documentary sets only, supplied by the historian Ljubic.

Whether and how these gaps affected the completeness and reliability of Kispatic's work will be considered in the following sections.

\section{Historical background: settlements and documents}

\subsection{Geopolitical features}

The main reason for considering this area separately from the rest of the Balkan peninsula lies in the common geopolitical features characterising the settlements distributed along the eastern shore of the Adriatic sea. It is worthwhile mentioning that this separation can be observed, at least for Dalmatia, also in the geomorphology of this area. This was described with few but accurate words by a historian at the beginning of the 20th century: «[...] from the Quarnero to the Bocche di Cattaro [Boka Kotorska], a series of deep inlets and bays, with rocky mountains [Dinarides Alps] rising up behind [...] Dalmatia is always a narrow strip, and [...] southwards it becomes even narrower, the mountain ranges at various points coming right down to the water's edge» (Villari, 1904).

Important towns were settled by Greeks (Epidaurus, Cavtat, identified today as the place of Ragusavecchia, near Dubrovnik) and Romans (Salona, today Solin, near to Spalato/ Split) in this narrow strip, which has been since then a «border-land», owing its importance to its harbours along the most travelled sea-route linking the northern European countries to the Eastern world since the Antiquity. Some of these settlements were established in a favourable position on the coast as the last stop of the land-routes coming from the Far and Near East (Villari, 1904). Most of the towns developed from what originally were military posts and then fortresses giving shelter to travellers on their way from Constantinople to Venice, for instance, or to merchants fearing to be attacked by the ever-present pirate activities.

South of Kotor, both the morphology and the density of settlements change dramatically: low coasts and bays less suitable to shelter ships and their cargo, after Dulcigno/Ulcinj (famous for being a pirate nest) the first safe stop was Durazzo/Dürres; the town of Corfu/Kerkyra in the eponymous island took the place of the mainland as privileged stop, especially after it became a Venetian dominion (late 14th century).

This situation is indeed strictly related to and affected by the longest cultural and administrative influence that the Eastern Adriatic experienced: in the early 10th century the flourishing Republic of Venice expanded its dominion towards the Eastern Adriatic when its territorial extension in the north-eastern Italian mainland was still limited by the power of neighbouring Communes and ruling families. But the prevalence of Venice in the Adriatic sea depended upon the logistic supports located on the eastern coast, and this lasted, with ups and downs, for quite eight centuries, until the fall of the Republic (1797). A far as the southernmost part of the area under investigation is con- 
cerned, Venetian dominion on Albania extended at its peak to Dürres only up to early 17 th century (Eickhoff, 1991).

In Dalmatia, Venetian influence was particularly relevant to the language, both spoken and written. Still under Habsburg dominion (mid 19th century), Italian was widely spoken in the main Dalmatian towns, Zara, Spalato, Ragusa and Cattaro. The official languages of the Republic of Ragusa (1420-1808) were Latin, a residue of Roman and Byzantine domination, and the Italian spoken by the Venetian officers ruling in this area with varying luck between the 10 th and the 18th century. It is not surprising that nineteenth century historiography on Dalmatia has a sound tradition in Italian, Croatian and German. The renowned geographical and historical description of Dalmatia by Petter (1834), who spent four years at Ragusa and six at Spalato since 1823, was published in Italian and then in German (Petter, 1857).

\subsection{Observation points and documents}

As a matter of fact, the places which, in Kispatic's compilation, are the main observation points of the seismicity of this region, are the same from which observations of earthquake effects are available in the long-term period.

A compendium of information on three towns, Zara/Zadar, Ragusa/Dubrovnik and Cattaro/Kotor, chosen because they have the longest observation tradition, is given in the following, going from north to south. This is intended to show the main geopolitical changes they have passed through and what historical sources have been investigated so far, with special reference to Kispatic's contribution, and what is the potential set of historical records still to be looked into.

From being a town of the Kingdom of Croatia in the 10th and 11th centuries, Zara/Zadar (fig. 3) became in 1202 part of the Venetian do-

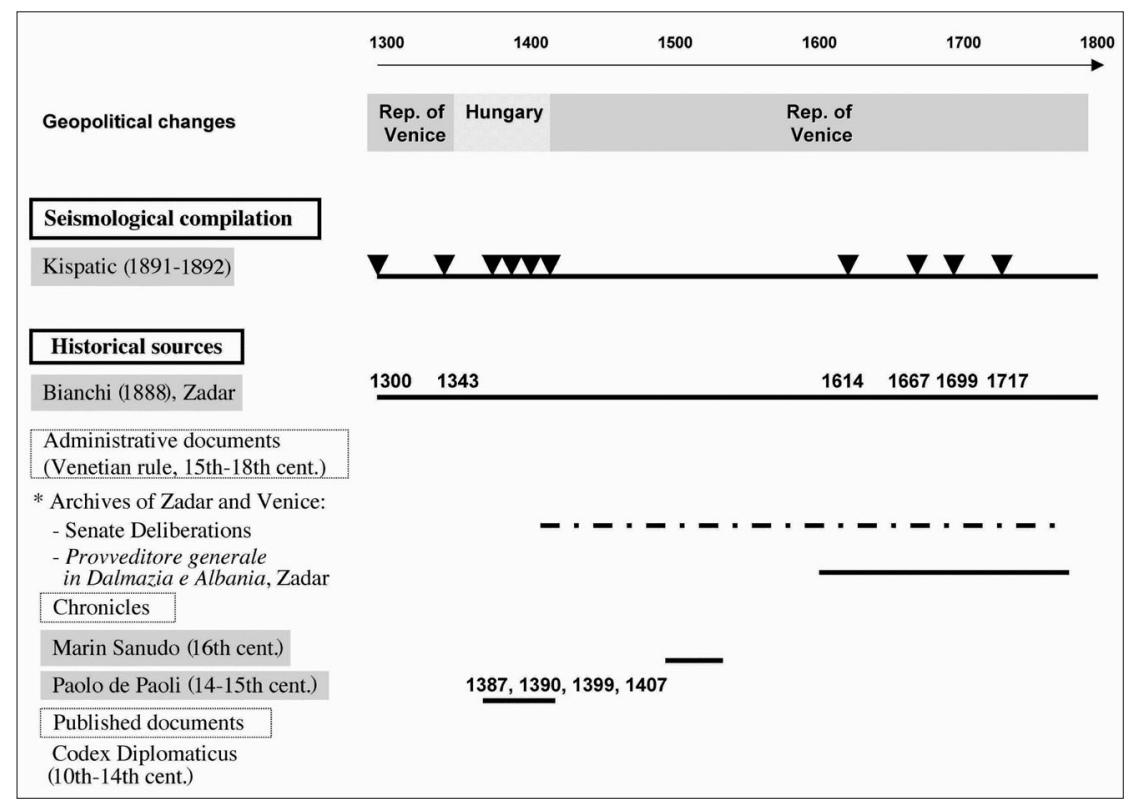

Fig. 3. Zadar: seismic and historical background. Major earthquakes described by Kispatic (1891-1892) are evidenced on the timeline by triangles. Earthquake dates are shown on the time interval spanned by the historical sources (shaded boxes) supplying the record to Kispatic. Other sources are those available for Zadar and not systematically investigated so far. 
minion in Eastern Adriatic. The town was a bishop's see since 1125, decorated by many churches (Brunelli, 1913). In 1358, Zara was re-conquered by the Hungarian and Croatian king, became an independent Commune between 1382 and 1409, and was again under the Republic of Venice until 1797. Since late 16th century the officer taking care of Venetian territory in Eastern Adriatic was the «Provveditore Generale in Dalmazia e Albania» (Governor General of Dalmatia and Albania), seated at Zadar. The long history, and in addition the important administrative role, of Zadar makes it an important observation point for events affecting the Eastern Adriatic. For these reasons, documentation of the town life is substantial, and the Archive at Zadar is still considered one of the main repositories for studying Dalmatia and surrounding regions. It should be stressed here that Kispatic (1891-1892) (see above and shaded sources in fig. 3) only partially used the potential of information available for Zadar.

The town of Ragusa (today Dubrovnik) was established by the survivors of the Avars' raid in Dalmatian Epidaurus (Cavtat) in the seventh century (Krecic, 1972) and the importance of the new settlement as a port city on the eastern coast of the Adriatic is well attested since the 12 th century. Becoming independent from Venice since 1420 (Villari, 1904; Carter, 1972; Sugar, 1977), the Republic of Ragusa, though a small city-state, never abandoned its role at the core of Dalmatian history. Its harbour maintained its importance, and the Ragusans specialised in the particular trade of collecting and spreading intelligence among the main actors of the Mediterranean in the Modern Age (Ottoman Empire, Spain and Venice) (Preto, 1994). Since 1526 Ragusa paid an annual tribute to the Sublime Porte, the powerful Ottoman neighbour with whom the small Republic had to cope for centuries. The heavily damaging 1667 earthquake (Guidoboni and Margottini, 1988) brought a serious crisis to Ragusan finances and trades which took decades to overcome (e.g., Carter, 1972; Di Vittorio, 1983). The city-state lost its independence in 1806, after the dominion of Dalmatia passed from France to Austria.

Late medieval chronicles on Ragusa are available and published in the collection of
Monumenta spectantia historiam Slavorum meridionalium (Annales Ragusini, 15th cent; Chronica Ragusina, 15th cent.). This material has been abundantly used by later authors of histories of Dubrovnik (Razzi, 1595; Luccari, 1605) as well as by modern historians. Published separately, but worth mentioning here is the chronicle by Filippo de Diversis Quartigiani (1440), who wrote an account of the buildings and customs of Dubrovnik. According to Carter (1972), the original manuscript is in the Franciscan monastery in Dubrovnik. Unfortunately, no earthquakes are mentioned in the portion edited by Brunelli in 1882. For the Modern Age, the repository which should be investigated, aiming at an improvement of our knowledge of the long-term seismicity of Dubrovnik, is the Archive of the city-state, described as one of the richest in the Mediterranean area by many historians dealing with its documentation. The typology and amount of available documents are described in details both by Carter (1972) and by Lume (1977).

Cattaro/Kotor (fig. 4) owes its birth and increasing importance to its strategic location in the «Boka Kotorska», at the end of a long and narrow bay. Historical tradition for this town is scarce; established around the 8th century, it was in the sphere of influence of the Byzantine empire until the end of the 11th century. After some time under Serbian influence, it became a Venetian stronghold in 1420 until the fall of the Republic (1797). An officer appointed from Venice took care of the administration and of the trade development of Cattaro after the 15th century. For this reason the bulk of information on events involving this place has to be looked for in the Venetian archives storing the documents produced by the local governor (fig. 4). Its surroundings were small and the walls around the town (fig. 5) were for centuries the only physical separation from its powerful Ottoman neighbour.

\section{Major earthquakes in the Eastern Adriatic (14th-early 19th century): a review}

The material presented in this paper aims at contributing to a review of the existing knowledge of the seismicity of the Eastern Adriatic 
A survey of the past earthquakes in the Eastern Adriatic (14th to early 19th century)

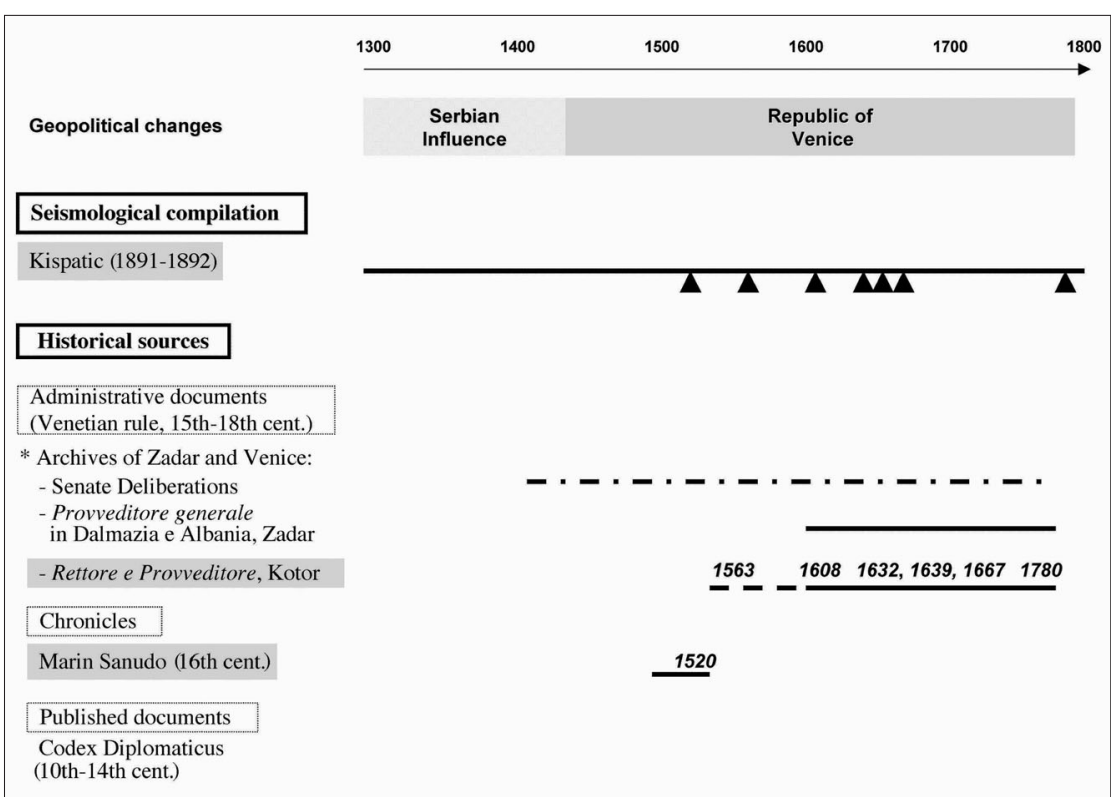

Fig. 4. Kotor: seismic and historical background. Major earthquakes described by Kispatic (1891-1892) are evidenced on the timeline by triangles. Earthquake dates are shown on the time interval spanned by the historical sources (shaded boxes) supplying the record to Kispatic. Other sources are those available for Zadar and not systematically investigated so far.

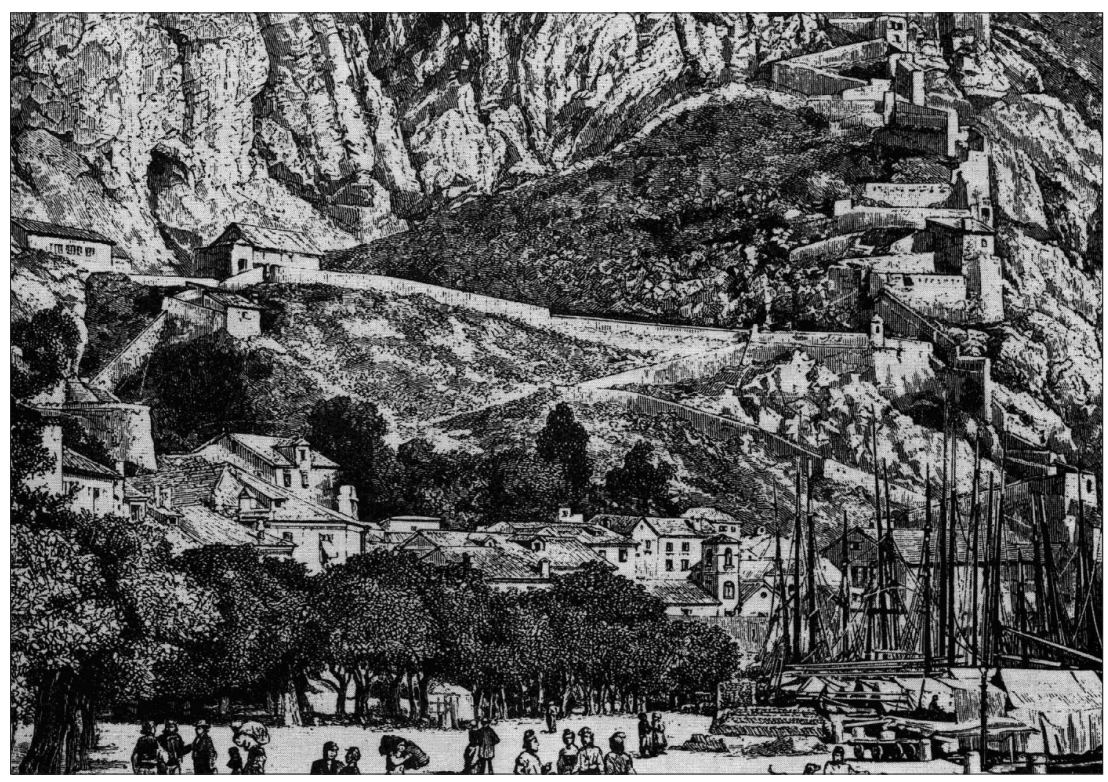

Fig. 5. The walls of Cattaro/Kotor in a 19th century drawing. 
from the point of view of historical records, and specifically those made available from seismological compilations and from the result of recent investigations.

Selected case histories are introduced to highlight the state-of-the-art and the potential of the information, still unexploited, which could seriously increase the amount of intensity data points, for major earthquakes mainly, and thus improve the completeness and reliability of the parameters of current earthquake catalogues.

Both the overview and the case histories have been addressed in two time frames: 1300 to 1529 and 1530 to 1806 . This ad hoc division roughly follows the main geopolitical changes in the area described in the previous chapter and is used to focus the analysis on the most relevant sets of documents available for each period with respect to earthquake observations.

\subsection{Up to early 16th century}

Seismicity up to 1529 clusters around Zadar and Dubrovnik (fig. 6): for the rest of the area in this study few earthquakes are catalogued, scattered both in time and space.

\subsubsection{Zara/Zadar}

The main historical sources dealing with earthquake effects in Zadar have been identified

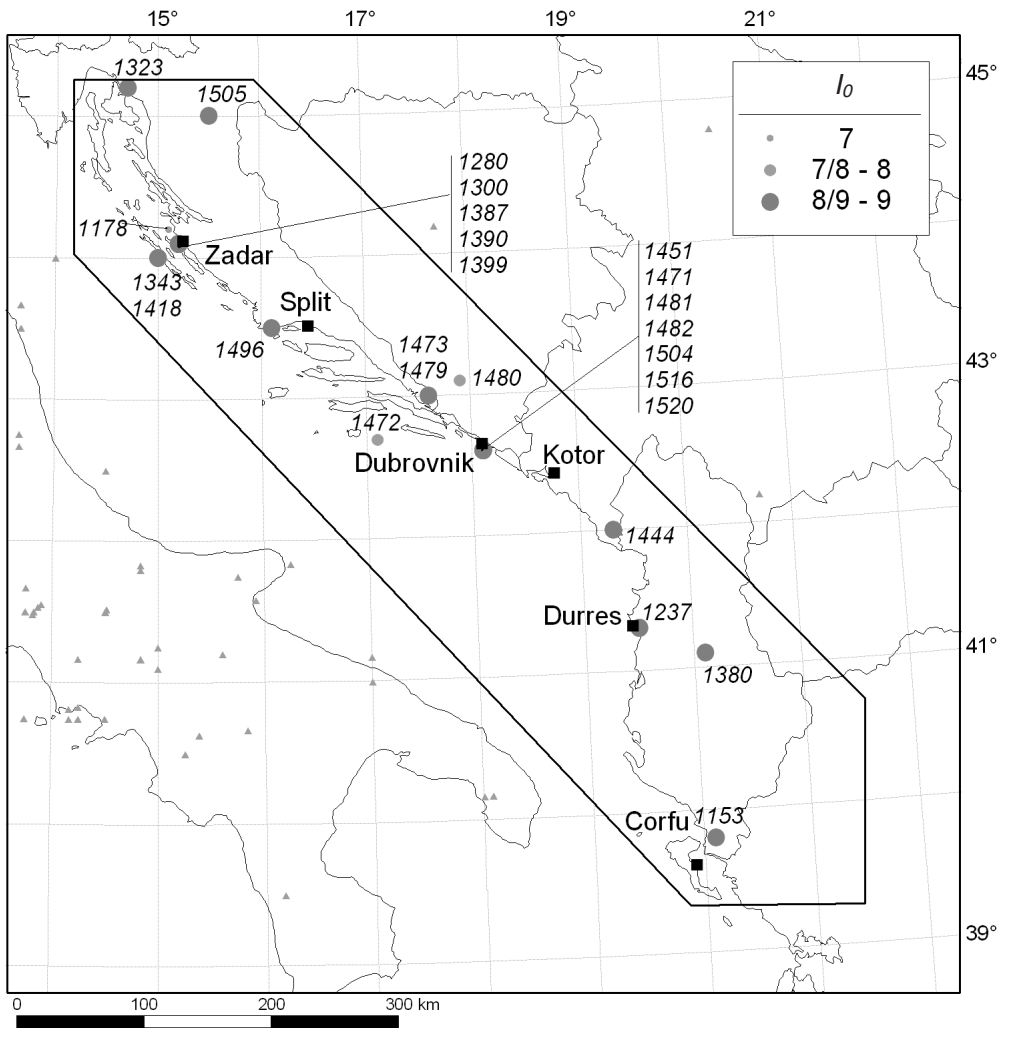

Fig. 6. Seismicity in Eastern Adriatic between 1000 and 1529 according to parametric earthquake catalogues. Earthquakes here considered are those from 1300 to 1529. 
through Kispatic (fig. 3). The most important one, from which comes the information on four earthquakes affecting Zadar at the turn of the 15th century, is the «Memoriale Pauli de Paulo Patritii Jadrensis», as Kispatic quotes it. But what is the original source and where is it?

This «Memoriale» and other medieval chronicles for Zadar and Split were published by Giovanni Lucio from Traù/Trogir in 1666, as an appendix to his «De Regno Dalmatiae et Croatiae». This outstanding volume is definitely the most important published contribution on the history of the Eastern Adriatic from 10th to mid 17 th century. Its main value, at least for our purposes, lies in the large use Lucio made of original documents, from the administrative and ecclesiastic archives of both Zadar and Split, partially or entirely reproduced in his book.

The original manuscript and three later copies of Paolo de Paoli «Memoriale» have all been lost, while the copy used by Lucio seems to be stored at the Vatican Library (Brunelli, 1911). Paolo de Paoli lived in Zadar and described relevant episodes of everyday life in his town from 1371 to 1408 . In fact, one line is devoted to 1371 , then he (or Lucio who transcribed the chronicle) jumps to 1378; the chronicle widens its horizons and includes both personal and town affairs in some detail from 1380 to 1408 . How detailed the record by Paolo de Paoli is, is not easy to assess, because we have to rely upon Lucio's transcription of his chronicle and because no other chronicles are at hand to make a sensible comparison.

Table II reports the information made available by him on earthquakes in Zadar at the turn of the 14th century.

How have these earthquake records been interpreted, are they included in current parametric catalogues, how have they been processed in terms of location and size?

Table II. Records on earthquakes at Zadar between 1387 and 1407.

\begin{tabular}{|c|c|}
\hline Earthquake date & Paolo de Paolo (15th cent.) \\
\hline 5 March 1387 & $\begin{array}{l}\text { «Anno } 1387 \text { die } 5 \text { Martii, hora tertiarum fuit in Jadra terraemotus magnus». } \\
\text { [In the year 1387, on March 5, at the third hour, there was a great earthquake at Zadar.] } \\
\text { [Lucio ed., 1666, p. } 424 \text { ] }\end{array}$ \\
\hline 5 Dec 1390 & $\begin{array}{l}\text { «Anno } 1390 \text { die } 5 \text { Decembris circa mediam noctem fuit terrae motus magnus». } \\
\text { [In the year 1390, on December } 5 \text { around midnight there was a great earthquake.] } \\
\text { [Lucio ed., 1666, p. 425] }\end{array}$ \\
\hline 6 Nov 1399 & $\begin{array}{l}\text { «1399 } 25 \text { Iunii [...] } \\
\text { Eodem anno die } 21 \text { Oct. hora quasi vesperarum fuit max. terraemotus in Iadra bene sep- } \\
\text { ties successive, ipsorum primus fuit terribilissimus, et nocte sequenti similiter fuerunt } \\
\text { plures, et etiam nocte post diem } 24 \text { ejusdem men. Circa mediam noctem et circa matuti- } \\
\text { nos fuerunt terrae motus, et per omnes dies inter diem, et noctem usque ad dies } 13 \text {. Sub- } \\
\text { sequentis modo cessavit terrae motus, et deinde die } 6 \text { Novem. hora quasi vesperarum fuit } \\
\text { similiter unus magnus et terribilis terrae motus». } \\
\text { [1399, June } 25 \text {... In the same year, October } 21 \text {. Around Vespers there was a very strong } \\
\text { earthquake in Zadar, for seven times, and of them the first was the worst, and the fol- }- \text { and } \\
\text { lowing night there were many too, and also in the night after } 24 \text { of the same month } \\
\text { around midnight and around matins earthquakes occurred, and for many days, day and } \\
\text { night, until the } 13 \text { th day of the following earthquakes stopped, and then again on No- } \\
\text { vember } 6 \text { around Vespers a great and terrible earthquake happened.] } \\
\text { [Lucio ed., 1666, p. } 430]\end{array}$ \\
\hline 25 June 1407 & $\begin{array}{l}\text { «1407. [Die martis Iunii } 21 \text { consecrata fuit Ecclesia S. Grisogoni de Jadra] die sab } 25 \\
\text { Iunii in aurora fuit vale terribilis terraemotus». } \\
\text { [1407. On Tuesday June } 21 \text { the Church of St. Grisogonus from Zadar was consacrated } \\
\text { and on Saturday June } 25 \text { at daybreak there was a really terrible earthquake.] } \\
\text { [Lucio ed., 1666, p. } 438 \text { ] }\end{array}$ \\
\hline
\end{tabular}


Three are listed and have been located at Zadar (fig. 6), with an epicentral intensity equal to 9 MSK (Shebalin et al., 1974). Even if the 1407 earthquake is also reported by Kispatic (18911892), it is not included in current catalogues.

No new records have been found on these events, Zadar being still the only place about which information is available. As for the damaging effects, the usual wording by Paolo de Paoli «terraemotus magnus fuit» (a large earthquake occurred) is generic and needs to be interpreted through some hints taken from other places in his same chronicle. After each recorded event, nothing changes in Zadar life, measured by the customary administrative meetings. But the chronicler is very precise about day and hour of the earthquake, as he is in the case of the burning of a single building ( $\ll 1381$-die 10 mens. Sep. Ea die de nocte combusta fuit domus») or of an uncommon atmospheric phenomenon ( $« 1387$ - die 8 Jan. In caelo splendor magnus»). These considerations, and a thorough reading of Paolo de Paoli «Memoriale», strongly suggest that the epicentral intensity of the four earthquakes affecting Zadar between 1387 and 1407 is overestimated and in need of a reappraisal.
Also Bianchi (1888) made use of Paolo de Paoli and other later sources, very imprecisely referenced to and only in his introduction. From him Kispatic took the information on some earthquakes in the 12th century and in the first half of the 14th century (see fig. 3). A supplement of investigation on this earlier period should cast light on these poor data, but both this information and Bianchi's reliability will not be further considered here. Nonetheless it is worth noting that: i) the other chronicles for this area edited by Lucio (1666) in the same volume as the «Memoriale» cover 13th and 14th century; ii) such chronicles register natural phenomena (eclipse, lightning) and damaging events (fire) but do not mention earthquakes.

\subsubsection{Ragusa/Dubrovnik}

There are few but reliable sources for medieval Ragusa (Annales Ragusini, 15th cent.; Chronica Ragusina, 15th cent.; Filippo de Diversis Quartigiani, 1440). It comes consequently as a surprise that no records on earthquakes affecting

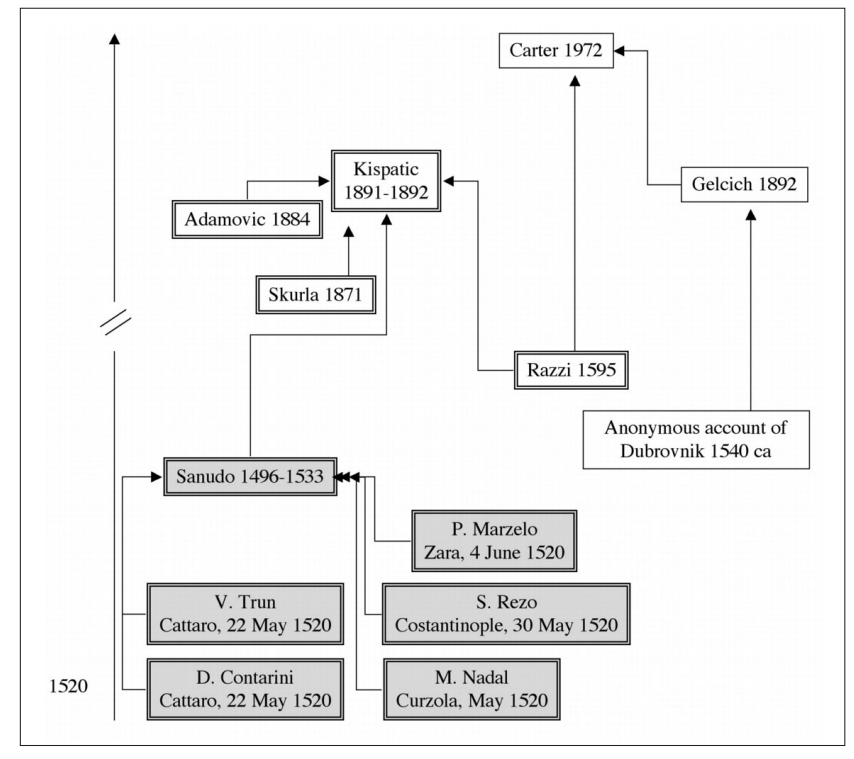

Fig. 7. Relationships between seismological and historical compilations and coeval sources on the earthquake of 17 May 1520 . 
the town are supplied by Kispatic before 1481 . On the basis of the catalogue by Traijc (1961), current parametric catalogues (Shebalin et al., 1974; Herak, 1995) locate the first earthquakes at Ragusa in 1451 and 1471, while the 1472 event is attested by Kispatic through Skurla (1871) and is located to the west of the town (fig. 7). As already said, when the only source of current catalogues is another catalogue, one faces a dead-end on the way to the original sources.

Recent histories of Dubrovnik (Carter, 1972; Krecic, 1972) are not more informative about earthquakes before the one in 1520, with the exception of Villari (1904). On the basis of Gelcich (1899) he wrote: «The year 1395 proved an unfortunate one for Ragusa [because of] heavy im-

Table III. Records on earthquakes at Ragusa/Dubrovnik (late 15th to mid 16th century).

\begin{tabular}{|c|c|}
\hline Earthquake date & Serafino Razzi (1595) \\
\hline $\begin{array}{l}14 \text { Feb } 1481 \\
5 \text { hours in the night }\end{array}$ & $\begin{array}{l}\text { «Dell'istesso anno } 1481 \text { alli } 14 \text { di Febraio, intorno alle cinque hore di notte, venne } \\
\text { in Raugia un terremuoto grandissimo, il quale fece gran danno, e rouine di case». } \\
\text { [p. 64] }\end{array}$ \\
\hline (*) Feb 1482 & $\begin{array}{l}\text { «'anno } 1482 \text { del mese di Febraio, vennero di nuovo grandissimi terremuoti à } \\
\text { Raugia, e per tutto il contorno». } \\
\text { [In the year 1482, in February strong earthquakes hit again Dubrovnik and sur- } \\
\text { roundings, p. 64] }\end{array}$ \\
\hline 26 Sept 1482 & «Et alli 26 di Settembre di nuovo furono terremuoti». [p. 64] \\
\hline $\begin{array}{l}28 \text { Nov } 1496 \\
17 \text { hours }\end{array}$ & $\begin{array}{l}\text { «ell'anno } 1496 \text { alli } 28 \text { di Novembre, à hore } 17 \text { essendo congregato il Con- } \\
\text { siglio generale in Palazzo, venne un così fatto terremoto, che dubitarono non } \\
\text { rouinasse il Palazzo, e che non morisse tutta la nobiltà. Ma Dio grazia non } \\
\text { seguì tanto male». [p. 68] }\end{array}$ \\
\hline $\begin{array}{l}(*) 7 \text { Dec } 1504 \\
\text { Tuesday }\end{array}$ & $\begin{array}{l}\text { «el } 1504 \text { alli } 7 \text { di Dicembre, in Martedi, venne un grandissimo terremuoto, il } \\
\text { quale guastò molti edificij». } \\
\text { [On December } 7 \text { th, Tuesday, a strong earthquake caused damage to many build- } \\
\text { ings, p. } 71]\end{array}$ \\
\hline $\begin{array}{l}(*) 17 \text { May } 1520 \\
11 \text { hours }\end{array}$ & $\begin{array}{l}\text { «Dell'anno M.D.XX. alli } 17 \text { di Maggio, à hore } 11 \text { nella festa della Santissima As- } \\
\text { censione, venne in Raugia un terremoto tanto grande [...]». [p. 75] (The com- } \\
\text { plete text is in the Documentary Appendix). }\end{array}$ \\
\hline $\begin{array}{l}3 \text { Feb } 1534 \\
3 \text { hours in the night }\end{array}$ & $\begin{array}{l}\text { «Dell'anno M.D.XXXIIII alli tre di Febraio, festa di San Biagio, protettore di } \\
\text { Raugia, circa le tre hore di notte venne un gran terremuoto in detta città. Ma per } \\
\text { la Dio grazia non fe danno alcuno». [p. 81] }\end{array}$ \\
\hline $\begin{array}{l}13 \text { Aug } 1543 \\
7 \text { hours in the night }\end{array}$ & $\begin{array}{l}\text { «Alli } 13 \text { d'Agosto dell'anno istesso alle } 7 \text { hore di notte, venne a Raugia un gran- } \\
\text { dissimo tremuoto». [p. 101] }\end{array}$ \\
\hline $\begin{array}{l}6 \text { March } 1544 \\
14 \text { hours }\end{array}$ & $\begin{array}{l}\text { «'anno istesso alli } 6 \text { di Marzo, alle } 14 \text { hore, stando tutta la nobiltà alla predi- } \\
\text { ca in duomo, venne in Raugia un gran tremuoto: ma per la Dio grazia non fe } \\
\text { danno alcuno nella Città. Ma rouinò in Narenta l'habitazione del venditore del } \\
\text { sale per la Republica con tutta la salinaria». [p. 102] }\end{array}$ \\
\hline $\begin{array}{l}11 \text { Sept } 1546 \\
3 \text { hours in the night }\end{array}$ & $\begin{array}{l}\text { «Alli } 11 \text { di settembre } 1546 \text { alle tre hore di notte venne in Raugia un gran terre- } \\
\text { muoto». [p. 110] }\end{array}$ \\
\hline $\begin{array}{l}7 \text { Feb } 1547 \\
1 \text { and a half in the night }\end{array}$ & $\begin{array}{l}\text { «Et alli } 7 \text { di Febraio dell'anno seguente [1547] à un'hora, e mezzo di notte ne } \\
\text { vennero due altri, uno dopo l'altro: ma per grazia del Signore non fecero danno } \\
\text { alcuno». [p. 110] }\end{array}$ \\
\hline
\end{tabular}

$\left(^{*}\right)$ the earthquake date indicates events listed by parametric catalogues. 
positions on Ragusan trade [in the period of the wars between Hungary and Venice for the dominion over Dalmatia]. At the same time heavy rains flooded the city and its immediate neighbourhood, destroying all the crops, and on May 19 a severe earthquake, the first great shock felt in Dalmatia for many centuries, wrought great havoc».

The book in question (Gelcich, 1899) was published few years after Kispatic's (1891-1892) and this is probably the reason why it was not taken into account; a previous work by the same author on Ragusa (Gelcich, 1884) could have been unknown to Kispatic's collaborators. Further, as we have already noticed above, against all expectations, few are the local documentary sources about earthquakes in Ragusa used by Kispatic's seismological compilation.

Apart from those on the 1520 earthquake, all records between 1481 and 1547 derive from one unique source: the «Storia di Raugia» (History of Ragusa) by the priest Serafino Razzi (1595), originally from Lucca (Tuscany, Central Italy), who spent many years in Ragusa in the 16th century. The information (table III), as in the case of Zadar, is concentrated on Ragusa, as one could expect from a local chronicle. The exceptions are the records on the 1520 and 1544 earthquakes.

How has this information been processed by parametric earthquake catalogues? As evidenced in table III by an asterisk before the date, out of eleven records supplied by Razzi, and reported by Kispatic, only three have been included in current parametric catalogues: 1482, 1504 and 1520.

Catalogues list also an earthquake in 1516, mentioned by Kispatic through Adamovic (1884): «On May 6, before midday, at Dubrovnik an earthquake was felt and it lasted 18 months. Some mountains cracked and the earth opened in some places». Since this event is not mentioned by Razzi, who is considered a reliable and complete source for this period, even if he was not in Ragusa at that time, the record of the 1516 earthquake appears a doubtful one.

On 17 May 1520, at 11 hours, an earthquake struck central Dalmatia, causing considerable damage and some deaths. This is the only earthquake, before the 1667 one, known in some detail as to its effects in and outside Dubrovnik, both in seismological compilations and histo- ries of Dubrovnik and Dalmatia. But it is also the first earthquake for which information from Venetian sources plays a fundamental role in letting us know the effects outside Dubrovnik.

As shown in fig. 7, Kispatic (1891-1892) relied upon Skurla (1871) and Adamovic (1884), but on coeval sources as well: Razzi (1595) and Marino Sanudo (1496-1533). What the latter reported (see Documentary Appendix) came from letters sent or read to the Senate in Venice by the son of Simplicio Rezo, merchant at Constantinople (on 30 May 1520), by Marciò Nadal, from Curzola (May 1520), by Piero Marzelo from Zara, who got a report from Ragusa (4 June 1520) and by Vicenzo Trun, governor at Cattaro/Kotor (22 May 1520) and Daniele Contarini, captain of a «galea» (galley) in Kotor (20 May 1520).

From Sanudo and Razzi we learn that the earthquake caused the following:

i) At Ragusa, part of the Lord's Palace collapsed, and some houses were seriously damaged; repair costs were estimated in «centomila ducati» (100 000 ducats) for Ragusa and 50000 ducats for the neighbouring places, not mentioned; according to Razzi 20 people died, but Venetian sources refer to 156 dead and 400 injured; the church of the Holy Saviour (San Salvatore or Sv. Spas) «was founded, as the inscription on the door states, as a result of a vow made by the government of the time, to commemorate those who suffered in the great earthquake of 1520» (Carter, 1972; see also Razzi, 1595, Documentary Appendix).

ii) At Cattaro, seven houses collapsed and several were damaged; the walls and the castle suffered too, the latter fissured especially in the gunpowder storeroom; no dead; Daniele Contarini was on his galley and the ship was rolling «as a leaf».

iii) At «Budua» (Budva) and at «Dulzigno» (Ulcinij) some minor damage.

In all, macroseismic effects recorded for this earthquake make it the largest event in the history of Dalmatia before 1667, and its maximum intensity could be estimated as 8-9 or 9 in EMS98 at Ragusa/Dubrovnik.

\subsubsection{South of Dubrovnik}

If there are relevant gaps in our knowledge of the seismicity of the northern part of 
the Eastern Adriatic between 1300 and 1529, the situation is even more dramatic south of Cattaro/Kotor (fig. 6). One earthquake only is listed by parametric catalogues, in 1380, located at Elbasan, an Albanian settlement far away from the Adriatic coast (for a discussion on the date of this earthquake through a historical interpretation of its epigraphic record see Evangelatou-Notara, 1993).

Seismological compilations for Albania (Mihailovic, 1927; Morelli, 1942) do not supply earthquake records for this period. Moreover, the possibility of easily collecting more records on this region appears to be very low. When dealing with Corfu, the situation does not change significantly. The island was under Venetian rule since late 14 th century, but the documents on the early Venetian period up to late 15th century are few, both at the State Archive of Venice (Da Mosto, 1937-1940) and locally (Gueze, 1970).

\subsection{Under Venetian rule and influence (early 16th to 18th century)}

Patterns of seismicity deriving from current parametric catalogues are different for the second time frame, 1530 to 1806 (fig. 8). In fact, the doubtful 1530/1531 earthquake is the only event located by catalogues at Dubrovnik between 1530 and 1667 and after 1667 until the mid 19th century. With the exception of 1667 , epicentres migrate from Dubrovnik to Kotor

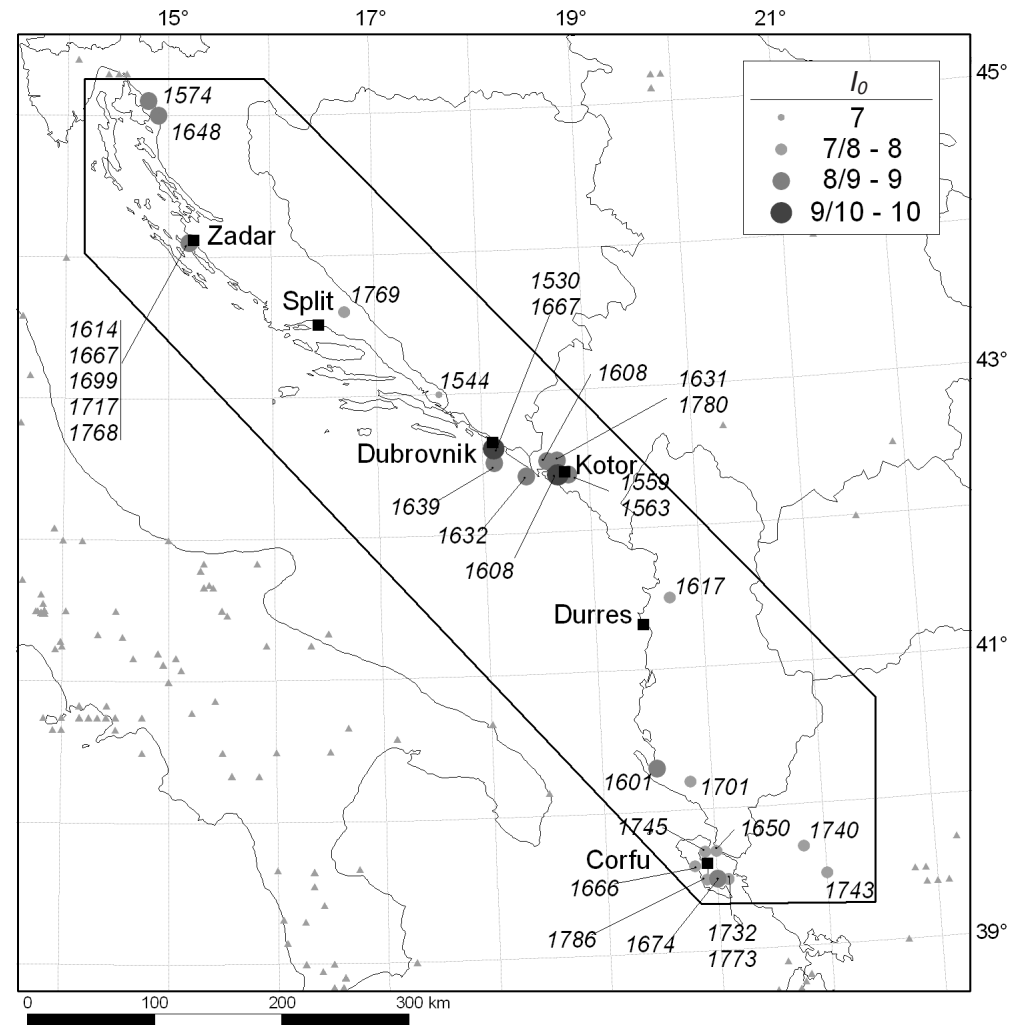

Fig. 8. Seismicity in the Eastern Adriatic between 1530 and 1806 according to parametric earthquake catalogues. 
and local seismicity appears at Corfu only eventually mid- 17 th century.

There are no specific chronicles dealing with Kotor, Albanian towns and Corfu in those centuries. In recent years, a series of investigations have been performed on the potential of Venetian documentary sources aimed at understanding the seismicity of the Southern part of the Eastern Adriatic in this time frame. Their main results are reported in the following, going from Corfu northwards.

\subsubsection{Corfu}

Seventeenth century Corfu was the seat of the Venetian governor of the «Three Islands» (Corfu, Kefalinia and Zakynthos) in the southernmost part of the Eastern Adriatic, where it merges with the Ionian sea.

An investigation of three earthquakes located by parametric catalogues in Corfu between 1650 and 1674 (fig. 8) was carried out through a systematic reading of dispatches of the local Venetian governor (Albini, 1999). A synthesis of the results is presented in the following.

Parametric catalogues (Papazachos and $\mathrm{Pa}-$ pazachou, 1989 and 1997) record an earthquake at Corfu in 1650 (no month no day), with $I_{0}=7$. The information is supplied by Chiotis (1863), relying in his turn upon a history of Corfu by Andrea Marmora (1672). Venetian documents (ASVe, 1651) do report an earthquake, but on 26 February 1651. The damage described was to a rampart in the walls, but though a survey was conducted the morning after the earthquake, cracks were discovered only eight days later. This makes less reliable the connection between damage and earthquake, and uncertainty on the actual effects due to the event is increased by the silence from places other than Corfu.

The November 1666 earthquake is listed in three parametric earthquake catalogues (Shebalin et al., 1974; Sulstarova and Kociu, 1975; Papazachos and Papazachou, 1989 and 1997, with $I_{0}=7$ ) as a damaging one. The latter catalogue took the record from the seismological compilation on Corfu by Partsch (1887), who in his turn used a bibliographical source published about one century after the earthquake
(Dresdnische Geleherte Anzeigen, 1756). The identification of a dispatch written on 20 November 1666 by the «Provveditore e Capitano» Foscarini (Museo Civico Correr, 1666) casts light on this episode: no earthquake was reported in Corfu, or in other places, and the collapse of Porta Rimonda, one of the entrances to the fortified town, is attributed by Foscarini to the continuous and heavy rains since August 1666.

The 1674 earthquake occurred on 16 January, about «ten hours of the night». Its effects are described in two dispatches by Giacomo Nani, governor and captain in Corfu (ASVe, 1674a) and Andrea Valier, Governor General «Da Mar», in charge of the Eastern dominions of Venice, then visiting Corfu (ASVe, 1674b). Both dispatches are dated 21 January and describe the effects at the following places:

i) Corfu, which suffered no damage;

ii) the region of Alefchimo, the southern part of the island of Corfu, where many houses and some churches were seriously damaged, some people died and many were injured;

iii) the village of Paxos in the northern part of the island, to the south-east of Corfu, suffered some damage as well.

From a third dispatch, by the newly appointed governor and captain in Corfu, Gritti (ASVe, 1674c) written six month later, we learn that for Parga, a fortress in the Epirus mainland, facing the island of Paxos, «recent earthquakes» are to be considered among the reasons of its bad state of repair. This set of information is particularly valuable because it concerns not only the main town, Corfu, but it describes effects at other places, including the mainland.

Though this earthquake is not included among those considered in this paper, because its epicentral location is between the Adriatic and the Ionian sea, for the sake of completeness the 20 February 1743 event should be mentioned here, since it seriously damaged places on both sides of the Adriatic sea and the Ionian Islands. It was one of the most damaging in Corfu, and a recent reappraisal of this event (Boschi et al., 1995), based on contemporary Venetian sources, assessed at the town of Corfu an intensity of 8 MCS. 


\subsubsection{Albania}

Venice never had a strong hold on Albania, and she lost her possessions in northern Albania, mainly Durazzo/Dürres, to the Ottomans early in the 17 th century. In Venetian documents the word «Provintia» is used by Venetian governors as synonymous with «Albania» and also to indicate just the northern part of modern Albania, roughly as far south as Scutari/Skhoder only. An investigation carried out on documents by the «Provveditore Generale in Dalmazia e Albania» (Albini, 1999) has shown that, though such material is available from the early 17 th century, the number of documents tends to decrease towards the end of the same century. The research was focused on checking whether what was happening in an area not under direct Venetian rule would be reported in the official documentation. Though this sample was disappointing in terms of information on earthquake effects, a parallel sample in other Venetian archival holdings has shown that a better observatory on Albania was Corfu's governor, who was reporting from many places situated inland and thus far from the actual borders with the Ottoman Empire (Albini, 1999).

\subsubsection{Cattaro/Kotor}

The «seismic history» of Cattaro is less known, but perhaps not less damaging than Ragusa's. The earliest earthquake located by the catalogues in Kotor is in 1559, and from that moment on and through the 18th century, damaging earthquakes in the Eastern Adriatic seem to cluster around both Dubrovnik (1667) and Kotor.

On 13 June 1563 around noon, an earthquake in Kotor made 168 houses collapse and left the rest seriously damaged. The Governor's Palace was hit and the Venetian governor of that time, Francesco Priuli, and his family died under the ruins, together with at least a dozen more. Kispatic took this piece of information from two dispatches, written in July and September by the newly elected governor in Kotor, Andrea Duodo. These dispatches should be found at the State Archive of Venice, but a preliminary investigation in some possible documentary sections storing this material (ASVe, 1563; ASVe, 1559-1581) did not succeed in retrieving the original documents. Anyway, a confirmation of the damage caused by this earthquake was found in a dispatch that the "Provveditore Generale in Dalmazia e Albania» wrote after the April 1667 earthquake (ASVe, 1667).

The same description given by Bonito (1691) through Giustiniani (1575-1576) is taken over by Kispatic, who relied upon the Venetian sources above mentioned, and upon an anonymous fly-sheet in German, «Newe Zeytung» (1564). The latter added a description of a subsidence phenomenon at the place then called «Belvedere», not identified so far, ending with a prophecy about the inhabitants abandoning that place in the years to come.

The description of effects is compatible with a large earthquake; but the scarcity of information from the surrounding places makes impossible at this stage to assess intensity at places other than Kotor, and for it as well it is possible only a (very) tentative evaluation of intensity as 9 EMS98.

In terms of epicentral intensity, the $25 \mathrm{Ju}-$ ly event of the 1608-1609 sequence affecting Kotor has been estimated equal to $10 \mathrm{MSK}$ (Shebalin et al., 1974), and is the largest earthquake ever located in Kotor by parametric catalogues.

Apart from Kispatic (1891-1892) no previous seismological compilation mentions this event, starting from Bonito (1691) to von Hoff (1840), Perrey (1850) and Mallet (1853); all, however, describe the 1563 earthquake.

Coeval Venetian documents (ASVe, 1608a,d-f,h; ASVe, 1608b,g,m; ASVe, 1608c; ASVe, 1609a,d; ASVe, 1609b,c), which were known and imprecisely summarised by Kispatic (1891-1892), describe the sequence as starting on 25 July 1608, St. James's day. News of the July earthquake reached the Senate in Venice and the Governor General at Zadar by means of a dispatch from Tomaso Contarini, governor at Kotor, dated 5 August 
1608 (ASVe, 1608b). Contarini wrote that the residences of the two high-rank public officers were damaged, one more seriously than the other, that the inhabitants were abandoning the town because the earthquakes were repeating, that the walls over the harbour were also damaged. The army barracks within the citadel were ruined, as well as some buildings by the seaside, where a bridge collapsed too. From «Castel Novo» (Herceg Novi), then in Ottoman territory, the news spread that damage was even worse than in Kotor, with many buildings in ruins and some deaths.

The second large earthquake happened on 15 September 1608, at 16:30. And this time it was the turn of the new governor, Francesco Morosini, to inform both Senate and Governor General that the situation had worsened (ASVe, 1608g). He and his family had not been killed by the partial collapse of the Palace, already shaken by the previous earthquake, simply because the earthquake had not happened during the night. Three houses belonging to merchants, buildings of good quality on the main square of Kotor, had the walls collapse. The clock tower was now leaning. Also damaged were the citadel and the fortification walls. One old woman died and there were some injured. The Venetian governor was also eager to know the consequences of the second earthquake in "Castelnuovo» (Herceg Novi), and thus sent there an informer with an excuse (a visit to an old relative): one third of the buildings had collapsed, as well as a portion of the castle walls, and within it havoc was great. There were neither deaths nor injured because the inhabitants were living in their villas outside the town for fear of a Spanish galley attack.

Smaller earthquakes continued to be felt until mid December 1608 (ASVe, 1608m). On early January 1609 heavy rains caused the collapse of three buildings which had been weakened by the repeated earthquakes (ASVe, 1609a). And another earthquake was felt «in the evening of St. Paul's day», that is on 25 January (ASVe, 1609d).

A tentative intensity assessment for Kotor and Herceg Novi for the 25 July 1608 earthquake could result in 8 EMS98 at both places.
Assessing intensity for the 15 September 1608 earthquake would not be free from the previous earthquake's influence on building stock and vulnerability, and would in reality mean to evaluate the accumulative effects of the two earthquakes. This is a delicate issue, still without agreed procedures, but a tentative estimate for macroseismic effects resulting from both events could be intensity 9 EMS98 in Kotor and Herceg Novi.

No information was found on an earthquake dated by Shebalin et al. (1974) on 14 May, with $I_{0}=9$ : letters and dispatches of the governor at Kotor are available and have been systematically investigated from the beginning of May 1608. In particular, the dispatch sent on 25 May by the governor in Kotor to the «Provveditore Generale in Dalmatia e Albania» deals with «things going on in Albania» but does not mention any earthquake (ASVe, 1608a). On the basis of this new evidence, the parametric record on the 14 May earthquake should be considered fake, probably a duplicate of the 25 July earthquake.

In this paper no space is given to the already mentioned 6 April 1667 earthquake, which caused serious damage both at Dubrovnik and Kotor (Guidoboni and Margottini, 1988). But since we are dealing with Venetian documents, it is worth mentioning that Venice tried to take advantage of the crisis induced to Ragusa/Dubrovnik by this earthquake, and put energy and money in strengthening Kotor, in open competition with the independent Republic of Eastern Adriatic.

Parametric catalogues for the Eastern Adriatic list no earthquakes with $I_{0} \geq 7$ in the area of Dubrovnik and Kotor between 1667 and 1780.

What has been shown about gaps and incompleteness in the sets of historical records supporting Kispatic's earthquake compilation, gives enough evidence to suggest a reasonable explanation of this «silent» period: the two main repositories, Venice and Dubrovnik, which potentially store the documentation on the history of this area in this time span, were not systematically investigated. This is further supported by the fact that a 
proper description of the 1780 earthquake is also a last-minute addition to Kispatic's compilation, in the appendix to his work. He owes this information to «the work by Prof. Srecko Vulovic, at Kotor. I had his personal permission to copy it and here I am reporting his text»(Kispatic, 1891-1892). The appendix gives supplementary information on the 1632 earthquake at Kotor as well, but this event will not be considered here.

In 1780 the Venetian «Provveditore Generale in Dalmazia e Albania», Paolo Boldrin, wrote in his 10 December dispatch (ASVe, 1780) that in the letter of 12 October (not available) the Governor in Cattaro had informed him of the damaging effects caused in Cattaro by an earthquake that occurred on 21 September. Damage was sustained by Budua and Castelnuovo as well. The governor in Cattaro made a first request for supplies needed for the restoration of the damaged buildings and a portion of the fortification walls. The Governor General appointed the engineer Gaetini to make a proper survey of the damage; the survey was made and sent to the Senate in Venice with the 30 January 1781 dispatch (ASVe, 1781). Unfortunately, the survey is not enclosed in the dispatch and the information on effects remains generic.

Much more detailed is what Kispatic found in Vulovic's work and reported in the appendix. This information, supplemented by reports on coeval French and Spanish press (Mercurio Historico y Politico, 1780; Gazette de France, 1780) is summarised below.

At Kotor, some of the poorest buildings laid in ruins and two children died under them; cracks and the fall of chimneys were the only damage suffered by more solid buildings; the cathedral was seriously fissured (Kispatic, 1891-1892).

At Castelnuovo/Herceg Novi, located at the entrance of Boka Kotorsks, the lighthouse collapsed and killed an old woman (Kispatic, 1891-1892).

Fissures opened in the ground between Cattaro/Kotor and Perasto/Perast, but damage spread inland to Scutari/Shkodër (Albania) (Mercurio Historico y Politico, 1780).

Within the «Bocche di Cattaro» (Boka Kotorska), the sea retreated from the coast and then violently went back (Kispatic, 18911892).

At Ragusa/Dubrovnik some buildings were damaged (Gazette de France, 1780).

The earthquake was felt in the north, as far as the Korcula island, midway between Dubrovnik and Split, and at Antivari/Bar, $50 \mathrm{~km}$ southwards of Kotor (Kispatic, 1891-1892).

\section{Discussion and conclusions}

The information sets supporting current parametric catalogues for earthquakes in the Eastern Adriatic between 14th and early 19th century have been traced and commented on with respect to their availability, reliability and completeness. It turns out that our knowledge of the seismicity of historical Dalmatia, coastal Albania and Corfu still relies upon those records collected by the seismological compilations produced between mid 19th and mid 20th century.

Gaps in the information such seismological compilations supplied the compilers of the parametric catalogues with, have been checked versus the actual availability of historical sources on the main observation points in the region, at the same time highlighting the potential of documentation still awaiting to be investigated.

In particular Kispatic's work on Dalmatia (1891-1892) has been analysed and a «map» of what sources and repositories have contributed to his compilation has been drawn.

The review of the major earthquakes focused on retrieving the known historical records in their original version, and on identifying and sampling historical sources so far not considered; this has been done according to two time frames, which made easier accounting for production and survival of local and coeval evidence.

Concerning the typology of sources supplying information on earthquake effects, town-centred chronicles largely dominate the first time frame, from the 14th to the early 16 th century. Conversely, the history of this area from the 16th to the 18th century so strongly influenced the document production 
and distribution that it made prevalent, in availability, investigation and use, the earthquake records contained in reports by Venetian officers, both in their official role and in the occasional ones of historian and reporter.

The documentary gap identified corresponds mostly to the documentation produced by the Republic of Ragusa (15th to early 19th century): documents from the historical archive at Dubrovnik were not considered by Kispatic, and its investigation, in the author's opinion, would bring to light outstanding evidence on effects of known earthquakes, as well as a confirmation of the time distribution of the seismicity of the central part of the investigated area.

Putting the historical records known to seismological compilations in the historical context in which they were produced has shown that their current parameterisation should be reconsidered in the light of a more systematic reappraisal of long-term seismicity of the Eastern Adriatic. The case histories presented showed that this of course depends on the collection of new evidence, but also on a revised interpretation of the records reading them in a historical and critical perspective.

Tentative intensity assessments have been given at those places for which details on serious damage effects were available, and this was possible in a few cases only.

On the other hand, this is an important limitation in estimating location and size of earthquakes in this area, since descriptions containing data useful to assess macroseismic intensi- ty are mostly restricted to one place only for each earthquake. In practice, with the historical earthquake records now available, the seismic histories of Zadar, Dubrovnik and Kotor could be completed and evaluated much easily than a full set of parameters for the earthquakes of 1407 at Zadar, or 1563 at Kotor.

An improvement of the knowledge of the past seismicity of the Eastern Adriatic is at hand: historical sources not fully exploited survived and are simply waiting for the historians and seismologists to ask them the right questions to disclose their potential of information on earthquake effects.

\section{Acknowledgements}

This paper owes much to the fruitful exchanges through the years with many colleagues. On the occasion of the publication of this volume my prevalent feeling is that I owe a heartful thank to my «masters in historical seismology»: Massimiliano Stucchi, Jean Vogt and Nick Ambraseys. Further, I could reckon on Roger Musson, to whom I am indebted for the writing of this paper. Previous and unpublished reports on this area were prepared with the collaboration of Carmen Mirto and Ilaria Leschiutta. I would like to thank Carlo Meletti for the preparation of some figures, Valentina Montaldo and Paola Migliavacca for supporting me in translation, transcription and bibliographical matters.

\section{Documentary Appendix}

- Records on 17 May 1520 earthquake

Serafino Razzi (1595)

«Dell'anno M.D.XX. alli 17 di Maggio, à hore 11 nella festa della Santissima Ascensione, venne in Raugia un terremoto tanto grande, che peggiorò dentro alla Città per valore di centomila ducati: e fuori per le ville per più di 50.mila. E vi morirono intorno à venti persone, e più assai ne rimasero ferite, e percosse. E narrano come da più persone fuori dalla porta di levante, luogo detto alle plocci: e eziandio da alcuni turchi, che quivi si trovavano, fù veduto il monte Vergato, che sopra stà alla Città, il quale minacciava di cadere sopra di quella. Ma opponendosi la Gloriosa Vergine con San Biagio, non lo lasciarono cadere. E fù in ringraziamento edificata una divota chiesa dell'Ascensione di nostro Signore, vicino al convento di San Francesco. E ci si và ogn'anno, in tal giorno, con pubblica, e solenne processione» (p. 75). 


\section{Marin Sanudo (1496-1533)}

[ad annum 1520] «A dì 30. [maggio] La matina, vene in Colegio ... fiol di Simplicio Rezo marchadante di zoie, è a Constantinopoli [...] Etiam lui averà letere di suo padre, [...] Dice come a dì 17 di questo mexe, fo el zorno di la Sensa, a hore [...], a Ragusi fo un grandissimo terremoto, qual ha ruinato parte dil palazo dei la Signoria e altre caxe, morto 12 homeni; siché ha fato danno in Ragusi per più di ducati [...] milia» (vol. XXVIII, coll. 562-563).

«Di Curzola, di sier Marchiò Nadal conte di [...] Avisa come a dì ..., fo il zorno di la Sensa, principiò uno gran terremoto a Ragusi, qual durò 9 zorni, over nove volte, ha ruinato parte dil palazo di signori e altre caxe, amazato homeni et fato gran danni; et uno San Biagio vardava verso Ponente, di marmo, il terremoto l'ha voltato; siché'l varda verso Levante» (vol. XXVIII, col. 564).

«[Giugno] Di Zara, di sier Piero Marzelo conte et sier Zuan Nadal Salamon capitanio, di ..., manda una relation di un de Ragusi, di uno novo terramoto stato de lì, la copia de la qual noterò qui avanti, videlicet a dì 3 di questo è stato sì gran terremoto a Ragusi che ha aperto uno monte lì contiguo, e l'aqua qual intrata dentro ruinà caxe etc.; el qual etiam fo a dì 17 Mazo el dì de la Sensa. Item, a Constantinopoli è stà uno altro grandissimo teramoto» (vol. XXVIII, coll. 621-622).

«A dì 18 [giugno][....] Di Cataro, di sier Vicenzo Trun retor et provedador, fo letere di 22.

Di uno terremoto seguito de lì el zorno di la Sensa, a dì 17 dil mexe, comenzò a hore una de dì, et à ruinato 7 case, risentito le mura di la terra et dil castelo, sfeso in certo locho, maxime dove stava la polvere. Per il che quella terra è in grandissimo spavento; fanno ogni dì processione. Scrive è stato etima de lì atorno, et maxime a Ragusi grandissimo.

Di Liesna, di sier Zaccaria Valaresso conte et provedador, di 7, tamen le altre fo di 9.[...]

Scrive come da Ragusi, per molti venuti, dicono quella terra esser in grandissimo spavento per li terremoti che ogni zorno usano dal dì di la Sensa in qua, quali hanno fato e fanno ruine grandissime, et ultimate è stà dito ozi l'ha ruinà la caxa di Jacomo di Zulian fidelissimo nostro, siché la terra è meza abandonata. El soradito vien di Constantinopoli, à ditto esser stato a Constantinopoli terremoto grandissimo et ruinato gran parte di le mure di quella città.

Exemplum

Sumario di una letera di sier Daniel Contarini soracomito, data in Cataro a dì 22 Mazo 1520, drizata a sier Jacomo Corner di sier Zorzi el cavalier procurator, ricevuta a dì [...] Zugno. Scrive, a Traù, Spalato et Liesna non poté trovar homeni da interzarsi, solum 6; siché l'era disperado e desiderava la morte. A dì 13 ditto vene lì a Cataro, dove per la Dio gratia se ha interzato, dil che è tutto resusitado. A dì 17, fo el zorno di la Sensa, a una hora de dì, fo lì a Cataro uno gran terremoto, il qual ha fato uno gran dano di caxe, ma non è morto niuno, neanche maculado niuno per la Dio gratia. Lui si atrovava su la sua galia, la qual tremava come una fogia; mai vide cosa più spaurosa; vete fino le montagne tremar. Questo teremoto è stà fino a Ragusi, e lì ha fato mazor danno che quì; à mazado 156 persone, magagnadi da 400. È stato etiam a Budoa et a Dulzigno, ma in questi luogi non ha fato tropo dano. A dì 20, questo Provedador ave una letera dil retor di Dulzigno, di 19, el qual li avisa come era zonto li uno bregantino armado [...]» (vol. XXVIII, coll. 625-627).

«A dì 19 [giugno][....] Fo scrito eri, per Colegio, a sier Vicenzo Trun retor e provedador di Cataro, in risposta di sue di 26 Zugno, dil terremoto sequito de lì, et che le mure si ha resentito, sì de la terra come dil castelo, e parte dil turion, con jactura di la polvere e ruinate alcune caxe. Pertanto fazi intender a quelli citadini fidelissimi si dolemo, e laudemo siino drizati al Signor Dio implorando misericordia, et il Zeneral presto sarà de lì et provederà a tutto. Et per una letera a parte, fo scrito al prefato rector laudandolo aver fornito et interzato la galia soracomito sier Daniel Contarini» (vol. XXVIII, coll. 630-631). 


\section{- Records on the 1608-1609 sequence}

\section{ASVe (1608a)}

Serenissimo Prencipe

[...] Tengo avisi del signor Rettor di Cattaro de 25 del passato [May] intorno alle cose di Albania ... In Zara alli 20 giugno 1608, Zangiacomo Zane

\section{ASVe (1608b)}

Serenissimo Prencipe

È gionto il Capitano Alfonso Forno con la sua compagnia, che per quanto vegio dalle littere della Serenità Vostra di 14 del passato da lui resemi sotto li 30 del medesimo et da me riverentemente ricevute vole essere di cento fanti come nel ruolo che mi ha presentato anco si vede, ma io li ho ricevuti con la sua persona, et quatro offitiali in tutto novanta tre, et di quelli che mancherano darò riverente esecutione à detta lettera, si come farò in tutte le altre parti che in esse si contengono. Et certo che sono venuti molto à tempo, si per il bisogno che vi era, come perche doppo che il giorno di S. Giacomo fece un terramotto in questa Città molto grande, et che quasi ogni giorno dal hora in qua se ne sente alcuno (seben piccolo) quasi tutti della Città fugono fuori, siche ella era poco meno che abbandonata, et seben io non permettevo a tutti la uscitta con intimationi, et altri modi necessarij, però fugivano ascosamente, et in casi tali in questi luochi massime, conviene passar molto destramente con queste genti per molti respetti. Questo terramoto hà fatto della rovina grande in tutta la città, ma in particolare al publico, per più di tre mille ducatti senza il danno delle muraglie buona parte sopra la marina che non è posibile che possino durare, et di fuori dove cadono non si può pontolarle a niun modo, et quando si potesse sarià un far scale da ascendervi sopra, oltre che sono appoggiate al palazzo alla casa del Signor Governatore che gli va dietro et à quella del Signor Camerlengo le quali cioè il pallazzo è in molte parti ressentito con qualche pericolo, quella del signor Governatore è del tutto rovinata, siche non si può più abitarla chi non la reffa tutta dalle fondamenta ne si può reffarla chi non reffà anco la muraglia, quella del Signor Camerlengo che continua dietro ad essa muraglia è in grandissimo conquasso et per l'accomodamento di questa è necessario l'istessa fatura come nelle altre, et chi non accomoda dette muraglie si core grandissimo rischio che tosto cadano et che la Città resti aperta. Molti Alogiamenti poi delli soldati in Cittadella sono caduti à terra, il luoco dalle monitioni da megli si è scoperto quasi tutto et in molte parti minatia rovina grande. Al scoglio degli Stradiotti sono cadute tutte le case, et il ponte che è di gran longezza è tutto portato via ma tutte queste cose convengono esser refatte et accomodate, pero mi è parso debito mio darne riverente conto a Vostra Sublimità perche possi prender quel espediente sopra di ciò che stimerà per sua prudenza necessario. L'istesso terramotto ha ancor fatto notabilissimo danno à Castel novo che gli sono cadute quasi tutte le case della Città, et buona parte delle muraglie con morte de molti per quanto si hà inteso, si che tutti li altri l'hanno abbandonata.

Di Cattaro li 5 agosto 1608, Tomaso Contarini, rettore e provveditore

ASVe (1608d)

Serenissimo Prencipe

[...] et in questa mia andata a Cattaro lascierò una buona banda di gente in quelle parti, affine che non segua alcun inconveniente. Grazie.

In Zara alli 24 agosto 1608, Zangiacomo Zane

ASVe (1608e)

Serenissimo Prencipe

[...] Hoggi sarà di ritorno la galea Moceniga, et io mi imbarcherò per passar a Cattaro conforme al comandamento di Vostra Serenità.

In Zara alli 28 agosto 1608, Zangiacomo Zane 


\section{ASVe (1608f)}

Serenissimo Prencipe

Ero quasi col piede in galera li di passati per trasferirmi a Cattaro, conforme all'ordine di Vostra Serenità, quando venerdì notte che fu alli 29 del passato [ebbi un] parosismo di febre [...]

In Zara alli 5 settembre 1608, Zangiacomo Zane

\section{ASVe (1608g)}

Serenissimo Principe

Luni li 15 del presente alle 16 hore e mezza il Terremoto non ancor satio di travagliare questa fortezza e di haver si lungo tempo tirato si fece sentir gagliardissimo con molto spavento e non poco pericolo di tutta la Città, havendo rovinate molte case, et conquassate quasi tutte le altre, ma in particolare doi camere di questo Palazzo, nelle quali dormivono quattro de miei figli, le ha redotte inhabitabili, et posso bene, e devo anco ringratiare infinitamente il Signore Iddio, che l'habbi mandato di giorno, si per il mio, come per il comune interesse, poiche se fussi occorso di notte, oltre la certa morte de miei, ne i letti, de quali caderno infinite pietre di non poca grandezza, sarebbero ancor stati ammazzati molti altri; che cosi ha solo causato la morte d'una povera vecchia, la quale (fuggendo per salvarsi) per il cadere d'alcune pietre fu accoppata, et ha ferito solo un soldato et il salinaro, ma di tutti doi si spera bene. Et perche sotto di esse camere vi è la sala delle armi la quale è molto pericolosa, ho fatto pero levarle di quel luoco, e riponere in miglior stanza, fino che sarà accomodata.

Ha gettato a terra molte muraglie, ma spetialmente tre case di mercanti particolari sopra la piazza, et parte della casa, dove soleva habitare l'Illustre Signor Governatore dalla quale si partì per il terremoto che tirò il giorno di San Giacomo, il quale fu così gagliardo che quella tutta mosse insieme con il quartiero de soldati posto in Cittadella e questo presente molto maggiore per quanto tutti questi signori affermano del primo l'ha del tutto rovinato, ne se li può rimediare, se non con il fabbricarlo di nuovo, il che è necessarissimo. Ho però fatto venire molti huomini di queste ville, accio levino li coppi, le pietre, et il legname di esso che potesse esser buono da opera, perche in ogni occasione di fabbricarlo, li vada minor spesa.

Ancora ha cagionato la rovina della casa del Carissimo Signor Camerlengo, nella quale, se non con evidente pericolo vi si può habitare, essendo tutta aperta, e quasi scoperta. Ha fatto molto danno nel loco delli melgi [sic], havendo rovinato parte della muraglia, et il resto sta con assai pericolo, il quale cadendo eccederia à grave danno della Serenità Vostra, perche rovinerebbe affatto tutti li melgi, li quali non si sanno ove riponere per sicurezza, non vi essendo loco al proposito in questa fortezza ne del publico ne del privato.

La muraglia sopra la marina per questo nuovo terremoto ha patito assai, et è ritirata in fuori molto. Nel Castello poi ha del tutto rovinato il coperto dell'Artiglieria, redutto in pericolo il loco della monitione, conquassata la casa del Carissimo Signor Castellano, fatto rovinoso il muro sopra la Porta, scoperto tutto il corpo di Guardia, et rovinate molte scale che conducono ad esso. Qui si vive con molto spavento, e pericolo per il grandissimo danno causato da questi terremoti; et in vero non è cosa al mondo, che possi più atterrire gli animi humani, quanto questi flagelli, poiche in tutte le altre si di guera peste fame et altro, la prudenza, et autorità degli huomini vale non poco, ma in questa nulla giova.

Non si resta però di far che la città sij ben custodita, poiche e per la quantità dei soldati e per la molta devotione del Signor Governatore e di questi Signori Capitani verso la Serenità Vostra è compitamente guardata. Tutto questo popolo ha posto ogni suo pensiero nel volere del onnipotente Dio, per il che si fanno continue orationi e Processioni per placar la sua ira, e certo che si vede gran conversione universale: onde voglio sperare che la Divina bonta sia per riceverle e per l'avvenire per guardarci da questi mali irremediabili. Subito, che fu gionto di qui il Signor Capitano Angelo Migliorati, mi presentò iuxta l'ordinario un mandato per polvere da distribuire alli suoi soldati per li loro bisogni accio lo sottoscrivessi, et vidi, che la polvere fina viene pagata ragione di soldi quattordici la lira, la quale so io, che molto più costa alla Serenità Vostra per tanto ho deliberato avvisarne gli illustrissimi signori sopra l'altelleria $[\ldots]$ 
Subito successo questo terremoto ho spedito un huomo a posta à Castelnuovo per intendere il danno, che havesse cagionato in quel loco, il quale con fingere d'andarsene a visitare un suo Barba, che habita in quella città procurò secretamente d'intendere ogni particolare, et ritornato mi referì come anco lì era stato gagliardissimo, e che ha conquassato tutta quella Citta havendo rovinate delle tre parte una delle case, et gran parte della Coltrina sopra il molo senza però offesa d'alcuna persona.

Il Castello drento della città è tutto conquassato, et ha nella muraglia una apertura gagliardissima, per la quale potrebbero doi al paro entrarvi drento. La fortezza di sopra è rimasta intatta, nella quale vi ponno essere da dieci Turchi; tutto quel popolo è ritirato alla larga fuori nelle loro ville, ne vi è nella città al presente alcuno, e certo che se da uno segno d'una Nave Ragusea non le fosse stato detto quattro giorni avanti, che tirasse il primo terremoto, che si dovessero salvare con accennarli che l'armata spagniuola di hora in hora doveva venire a svalligarli, e mettere tutta la Città a sacco, che percio da ogn'uno fu abbandonata, sarebbero gran parte di essi stati ammazzati dal terremoto, e queste sono l'istesse parole refertemi dal messo. Io sto assai allegramente, sperando nell' aiuto della Divina Bontà, e molto meno penserei di queste rovine, se di qui mi trovassi solo, e senza famiglia, benche per causa di questi così spaventosi terremoti m'habbi convenuto ritirar con tutti li miei sopra un Baluardo non già per pericolo delle camere della mia habitatione, le quali sono sicurissime e cadendo queste si profonderia questa Città, ma bensì per schivar la rovina della Torre dell'Horologio, che pende sopra esse camere, ne è molto sicura, minacciando da ogni parte rovina.

Starò vedendo qualche giorno quello faranno questi muri e poi procurerò di rimediari al meglio si potrà. Ho giudicato però esser bene far del tutto la Serenità Vostra riverentemente consapevole, acciò con il suo prudentissimo giuditio ordini quello si haverà à fare.

Non essendo neanco sino a' hora venuto di qui l'eccellentissimo Generale Zan, che pur si lasciò intendere di dover venire dal principio del mio reggimento per provvedere a' quello facessi bisogno; ma trattenuto da alcune sue indisposizioni non si crede perciò che per hora possi venire. Significandoli in oltre con l'istessa mia reverenza com'io andrò rimediando a quelle cose, che stimerò esser bisognose, come nell'habitatione de soldati, et altro, nelle quali spese vi potriano andare da Cento Ducati incirca.

Restando la Serenità Vostra sicura che in tutte le cose procurerò ogni avantaggio publico, come è mio debito, e molto più di quello, se fussi mio particolare interesse. Stimerei però essere anco bene che Vostra Serenità desse ordine, che per li bisogni di queste fabbriche fossero mandati di qui, dieci, o dodici mila coppi, e doi, o tremila tavole. Rimettendomi però in tutto, e per tutto alla somma sua prudenza, la quale ho voluto con ogni reverenza di ciò avvisare per anticipare il tempo, essendo sicuro che dell'eccellentissimo Provveditor Generale Zan le sarà per l'istesso effetto scritto. Grazie.

Di Cattaro alli 19 settembre 1608, Francesco Morosini Rettor e Proveditor

ASVe (1608h)

Serenissimo Prencipe

[...] Intendo per lettere da Cattaro che il terremotto fa sempre maggior progresso essendosi sentito di novo molto grande alli 15 del presente, che ha fatto gravissimi danni nella fortezza, et nel castello ancora, onde mi duole in estremo di non haver modo di potermene passare in quella città, come mi comandò già la Serenità Vostra, ma sa il Vostro Dio che non ho mai avuto commodo di poterlo fare, essendo prima stato impedito dalla indisposizione dalla quale non sono ancora intieramente ricuperato, et poi dal passaggio di questa principessa che mi ha levate le galere $[. .$.

In Zara alli 25 settembre 1608, Zangiacomo Zane

ASVe (1608m)

[...] che dire a Vostra Serenità se non che il terremoto si fa ancora sentire, et mercore li sedeci del presente ne tirorno tre ma non molto gagliardi, niente di meno hanno apportato assai confusione in questa Città, con tutto che da quel giorno in qua non se n'habbino più sentiti. [...]

Di Cattaro li 23 Decembre 1608, Francesco Morosini 


\section{ASVe (1609a)}

Serenissimo Prencipe

Sono da giorni dieci incirca che per gratia del Signore si vive da qui alquanto consolati per non sentirsi più terremoti li quali tanto afligevano questa Città; ma hora bene si incominciano manifestamente a vedere di quanto danno sijno stati à questo loco, essendo che li giorni passati per il conquassamento da essi cagionato et per le molte pioggie che sono state caderno tre case, ma senza alcun'offesa di persone et cosi questa fortezza per il passato in molte parti desolata viene anco con questi novi danni non poco destruta poiche quelle fabriche una volta cadute ò rovinate non vengono più da questi riedificate. Et quando io sperava di poter con qualche consolatione governare questi popoli vengo da molte altre bande di cattivi avisi oppresso, essendo che corre voce che nella Villa di Corenichi sopra di Pisano et lontana da esso loco miglia dieciotto si è scoperto il mal contagioso et che in una settimana sono morti da esso male cinque persone. [...]

Di Cattaro li 6 gennaio 1609, Francesco Morosini Rettor e Proveditor

ASVe (1609b)

Serenissimo Prencipe

Arrivai in questa città con felice navigazione à 13 del presente, [...] All'incontro dentro della citta, ha fatto gran rovine il terremotto, et molte fabriche pubbliche hanno patito estremamente, onde si come ho ordinato ad esso Capitano Cesare, che prenda nota, et faccio disegno diligente, e distinto di ogni cosa, così prima che io parta che sarà fra doi ò tre giorni, credo di dar ordine che sia principio a risarcire le cose più necessarie, et che non patiscono dilazione, come sono alloggiamenti de soldati, de quali un quartiero è interamente caduto a terra, magazeni de munizioni, casa del Governatore et alcune rovine nel Castello di sopra, ove andai l'altro giorno, et medesimamente il ponte al scoglio de stradiotti che io vidi, e dove smontai nel passare, che è rovinato del tutto, et che è necessarissimo; di tutto che poi con piu commodo e con maggior chiarezza, e distinzione darò conto a Vostra Serenità et tra tanto invio con le presenti nota particolare de legnami, ferramenti et copi che fanno bisogno per parte di esse fabriche, li quali le piacerà di mandar quanto prima. [...]

In Cattaro alli 20 Gennaro 1609, Zangiacomo Zane

\section{ASVe (1609c)}

Serenissimo Prencipe

Sabato passato che fu li 24 del presente io partii da Cattaro et havendo prima con esquisita diligenza vedute, et essaminate quelle rovine per occasione del terremotto, fù concertato fra l'Illustrissimo Proveditor et me, che immediate egli dovesse por mano à ristaurare il Quartiero de soldati della Cittadella, li Magazeni delle Munizioni, il Ponte al scoglio dei Stradioti, et quegli alloggiamenti; et alquanto di Muraglia in Castello che è risentita, et minaccia di cadere, perche queste sono operazioni grandemente necessarie, et non patiscono dilazione, et havendo io già scritto alla Serenità Vostra colla fregata ordinaria la quantità de' legnami, ferramenti et copi, che mi bisognano, mentre che tarderanno à comparire, attenderà S.S. Illustrissima à far fare la provisione delle altre materie di calcina, et pietre, et à tirar su i muri dove fanno bisogno, percioche al quartiero de soldati per ritornarlo habitabile si dovverà rifar il coperto, et i pavimenti, et passa 118 incirca di muraglia. A i magazeni si ha da rassettar i coperti, et farli circa 70 passa di muraglia. Et al Castello medesimamente bisognerà rifar circa 30 passa di muro; et al scoglio de Stradiotti sicome medesimamente potrà S.S. Illustrissima applicarsi immediate nel risarcimento di quelli alloggiamenti per li quali è bisogno di poco muro, così potrà anco attendere alla refattione del Ponte, essendovi li legnami, et la ferramenta et non mancandovi altro che li Palli, de quali si potrebbe provvedere parte nel medesimo territorio di Cattaro, e parte nell'Albania, ma perche questi dell'Albania che dovevano esser al numero di 11080 de quali doveranno essere di longhezza di passa 5173 et 30 di passa 6, per le informazioni che si hanno, potranno costare tre scudi l'uno con la conduttura, et crede l'Illustrissimo Signor Proveditor che quando la Serenità Vostra gli mandasse [...], si spenderia molto meno, doven- 
domi io sopra ciò riportare a S.S. Illustrissima vengo à dire à Vostra Serenità che esso Signor Provveditore stava aspettando in questo proposito il comandamento suo.

Le altre parti, che hanno bisogno di essere accommodate, sono la muraglia della città, il Palazzo del Rettore, la casa del Signor Camerlengo e quella del Signor Governatore et fabrica di altri magazeni, et alloggiamenti circa; che essendo noi conformi di opinione come per avventura le sarà scritto anche da S.S. Illustrissima resterà che da Vostra Serenità sia comandato ciò che le piacerà che si faccia. La muraglia risentita è in quella parte che guarda sopra'l molo, et comincia a piegarsi dodeci passa distante dal fianco della Cittadella, et continua per 40 passa di longhezza; i primi 25 passa pendono all'infuori un piede e mezo: doi: e fin doi e mezo: et il restante pende un piede e mezo et uno: et se bene si può quasi dire che essa muraglia non habbia patito se non dalla mettà in su, è nondimeno opinione nostra per maggior sicurtà che si cominci a rifabricarla dal piano naturale per tutto questo corso di 40 passa, alzandola al segno che ella è al presente di piedi 27 , ma facendola nel fondo di grossezza de piedi cinque, che venga a poco a poco ristringendosi, cosi che nella sua sommità resti piedi 4 cioè con mezo piede di scarpa di fuori, et mezo di dentro; il che apporterà anco maggior fermezza, et stabilità ad essa muraglia, perche quanto al fabricar sopra i fondamenti vecchi, si come si tiene per fermo da ogn'uno che essi non si siano mossi punto, così si conclude, che essendo sopra Palli non è dubbio alcuno, che siano più sicuri, che se si facessero da novo. Et perche in questa parte che è appo la porta vi è il volto, ove alloggia il corpo di guardia, il qual volto fa spalla nella muraglia, si giudica che sia meglio non fermarsi qui il volto, ma solo il pavimento, che servirà molto meglio, perche in occasione di altro terremotto non sarà così facile à conquassarsi; et con l'accomodamento di questa muraglia si torna in pristino anco il palazzo del Signor Rettore, il quale non ha patito altro, se non che essendosi allargata la muraglia, e disgionte da essa le travature de pavimenti, hanno minacciato di cascare, mancatole il suo appoggio. La casa del Signor Camerlengo che ha sotto di lei alcuni magazeni da sale, è fuor di modo risentita nelle muraglie dal pavimento in su, ma le muraglie inferiori non hanno patito niente, in modo che si è giudicato buon consiglio, provedendo al Signor Camerlengo di altra casa, abbassar il coperto di quella, che senza altra spesa servirà all'uso di prima per i sali. Per l'habitatione poi del Signor Camerlengo et del Signor Governatore si è pensato di comprar alcuni fondi de particolari contigui alla Muraglia, che sono tutto quel tratto, ch'è tra il Palazzo del Signor Rettor, et la casa del Signor Camerlengo et oltre di ciò alcuni altri posti all'incontro di spazio di passa 47 quadri, tutti i quali si come non costeranno più di 300 Toleri in circa et daranno commodità non solo di fabricarvi le dette case, ma anco de' Magazeni per il pubblico servizio, di che vi è di bisogno, così scosteranno le persone private dalla Muraglia, alla quale non è bene che habbino congionte le case. Havemo appo considerato che la Torre, ove sta riposta la polvere per l'artiglieria, è in sito tale, che si è scoperta da ogni parte, et sottoposta ad ogni ingiuria et machinazione di chi si sia, onde sarebbe a giudicio nostro, molto più sicuro ch'ella fosse riportata in una piazzetta, ch'è vicina alla Sentinella, et al quartiero della Porta del Gordichio [sic], che ivi starebbe senza tanto pericolo, et fuori di prospettiva. Queste sono tutte quelle cose che mi sono parse degne di considerazione et di provvisione delle quali non havendo potuto dar conto particolare a Vostra Serenità con le mie che le scrissi da Cattaro sotto li 20 del presente non ho voluto tardare a farla consapevole del tutto, affine che essendo tutte materie di molto momento, ossi ella colla sua somma prudenza deliberar tosto ciò che si doverà fare, poiche da quell'Illustrissimo Signor Rettor che è diligentissimo et volto tutto al publico servizio, sarà con ogni industria, e sollecitudine esseguito quanto le sarà comandato da lei, dovendo egli fra tanto andar preparando tutte quelle circonstanze, che possono esser necessarie a queste operazioni. Grazie.

Curzola à 30 Gennaro 1609, Zangiacomo Zane

\section{ASVe (1609d)}

[...] Il terremoto di qui si fece sentire la sera di S. Paulo et da quell'hora in qua si è acquietato, onde voglio credere che haverà preso buona licenza, che il Signore ce la concedi. Grazie.

Di Cattaro li 14 febbraio 1609, Francesco Morosini Rettor e Proveditor 


\title{
- Records on 21 September 1780 earthquake
}

\begin{abstract}
ASVe (1780)
Serenissimo Prencipe

[...] Quell'Illustrissimo Estraordinario [di Cattaro] con sue lettere 12 ottobre decorso spiega diffusamente il massimo terrore cagionato in que' sudditi, e li gravissimi danni che derivarono nelle private e in tutte le Pubbliche Fabbriche, Chiese, e Conventi da una gagliarda scossa di terremoto, verificatasi nel giorno 21 settembre antecedente, e mi accompagnò con molti fabbisogni le lettere pure de' Nobil Huomini Rappresentanti di Castel Nuovo, Budua, Rettore di Cattaro e Governator dell'Armi, li quali ragguagliano i medesimi mali anche in quelle Piazze, non senza grave danno come essi rappresentanti asseriscono nelle case di loro abitazione, ed effetti, supplicando anzi (massime quello di Budua che partecipa aver dovuto ritirarsi in altra casa di maggior affitto) che nel generale della sciagura siano tolte in riflesso anche le particolari loro convenienze. Accenna inoltre lo stesso Estraordinario che attesa l'indispensabile necessità ha dovuto far seguire sul momento provisionali ristauri dei Luochi Pubblici in Cattaro, tra quali il riffacimento d'un pezzo di mura per piedi 18 di antica costruzione che rovesciò dalla parte del Castello verso Montenero, e che per particolari politici riguardi esiggeva, com'egli scrive, istantaneo riparo.

In così dolorosa avventura, e veramente seria secondo i rapporti che mi derivano, ho colto l'opportunità del Tenente d'Ingegneri Gaetini, che attrovavasi a quella parte per altre pubbliche esiggenze, a cui ho rilasciata commissione immediata di riconoscer gli esposti danni e di estender i relativi Fabbisogni, che mi riservo di far tutti presenti all'Eccellenze Vostre tosto che li abbia con quelle avvertenze e previsioni che si convengono. [...]
\end{abstract}

Zara li 10 dicembre 1780, Paolo Boldrin, Provveditore Generale in Dalmazia e Albania

\section{ASVe (1781)}

Serenissimo Prencipe

[...] Già ho prevenuto l'Eccellentissimo Senato con il riverente mio Dispaccio n. 10 [ASVe, 1780] di aver commesso al medesimo Gaettini [sic], coll'opportunità, che attrovavasi a quella parte, di dover riconoscere anche i danni cagionati nella Pubbliche Fabbriche di quelle Piazze dalla scossa del Terremoto seguita nel giorno 21 passato Settembre, sicché in riscontro della prestata obbedienza mi presentò pure tutti quegli altri Fabbisogni, che accompagno, li quali riguardano la necessità di ristauri nelle Fabbriche stesse, esclusivamente da quelle di Budua, ove per combinazioni de' tempi non si trasferì, e da quelle ancora, che, come rassegnai nel Dispaccio medesimo, fece ristaurar tra le più bisognevoli il Nobil Huomo Estraordinario quasi su lo stesso momento.

In quel medesimo incontro osservò lo stesso Ufficial Ingegnere, e assicura con la tutta l'asseveranza nella stessa sua Relazione lo stato cadente, e pericoloso della Pubblica Loggia di Cattaro, a tal segno, che si mossero que' Giudici di far pervenire a questa carica con lettere di quel Nobil Huomo Rettor l'annessa supplicazione, che io non so dispensarmi, secondando l'istanza, e in vista delle circostanze, di rassegnare a Vostra Signoria [...]

Zara li 30 gennaio 1780 more veneto, Paolo Boldrin, Provveditore Generale in Dalmazia e Albania

\section{REFERENCES}

Adamovic, V. (1884): O tresnjama grada Dubrovnika, Biblioteca Storica della Dalmazia, Dubrovnik, Libro 7, 1-44.

AlBINI, P. (1999) Venetian documents on earthquakes within and at the western borders of the Ottoman Empire (17th18th centuries), in Natural Disasters in the Ottoman Em- pire, edited by E. ZACHARIADOU, Institute for Mediterranean Studies, Halcyon Days in Crete III, A Symposium Held in Rethymnon (Greece), 10-12 January 1997, 6788.

Albini, P. and M. StuCchi (1997): A Basic European Earthquake Catalogue and a Database for the evaluation of long-term seismicity and seismic hazard (BEECD), in 
Seismic risk in the European Union, edited by A. GHAZI and M. YEROYANNI (Brussel-Luxembourg), vol. 1, 53-77.

ANNALES RAGUSINI (15th cent.): Annales Ragusini anonymi item Nicolai de Ragnina, in Monumenta spectantia historiam Slavorum meridionalium, edited by S. NoDILO (Zagreb, 1883), vol. 14, Scriptores, vol. I, 1-328.

ASVe (Archivio di Stato di Venezia) (1559-1581): Senato, Dispacci, Provveditori da Terra e da Mar e altre cariche, Provveditore dell'Armata, b. 1196.

ASVe (Archivio di Stato di Venezia) (1563): Senato, Decreti, Mar, 5 March-28 August, f. 28.

ASVe (Archivio di Stato di Venezia) (1608a,d-f,h): Senato, Dispacci, Provveditori da Terra e da Mar e altre cariche, b. 423, 1608-1610: a) Zangiacomo Zane, Dispatch, Zara 20 June; d) Zangiacomo Zane, Dispatch, Zara 24 August; e) Zangiacomo Zane, Dispatch, Zara 28 August; f) Zangiacomo Zane, Dispatch, Zara 5 September; h) Zangiacomo Zane, Dispatch, Zara 25 September.

ASVe (Archivio di Stato di Venezia) (1608b,g,m): Senato, Dispacci, Rettori, Dalmazia, b. 7, 1607-1609: b) Tomaso Contarini, Dispatch, Cattaro 5 August; g) Francesco Morosini, Dispatch, Cattaro 19 September; m) Francesco Morosini, Dispatch, Cattaro 23 December.

ASVe (Archivio di Stato di Venezia) (1608c): Senato, Decreti, Mar, June-August 1608, Deliberation, 12 August, f. 180.

ASVe (Archivio di Stato di Venezia) (1609a,d): Senato, Dispacci, Rettori, Dalmazia, 1607-1609, b. 7: a) Francesco Morosini, Dispatch, Cattaro 6 January; d) Francesco Morosini, Dispatch, Cattaro 14 February.

ASVe (Archivio di Stato di Venezia) (1609b,c): Senato, Dispacci, Provveditori da Terra e da Mar e altre cariche, b. 423, 1608-1610: b) Zangiacomo Zane, Dispatch, Cattaro 20 January; c) Zangiacomo Zane, Dispatch, Curzola 30 January.

ASVe (Archivio di Stato di Venezia) (1651): Senato, Dispacci, Rettori, Corfù, b. 27, 1649-1651: Girolamo Contarini Dispatch n. 21, Corfù 21 February (1650 more veneto) 1651 S.V.

ASVe (Archivio di Stato di Venezia) (1667): Senato, Dispacci, Provveditori da Terra e da Mar e altre cariche, b. 497: Caterino Cornaro, Dispatch n. 247, Zara 24 September.

ASVe (Archivio di Stato di Venezia) (1674a): Senato, Dispacci, Rettori, Corfù, b. 32, 1668-1677: Giacomo Nani, Dispatch n. 62, Corfù 21 gennaio (1673 more veneto) 1674 S.N.

ASVe (Archivio di Stato di Venezia) (1674b): Senato, Provveditori da Terra e da Mar, Provveditore Generale da Mar, Andrea Valier, 12 ottobre 1671-26 novembre 1675, b. 941; Andrea Valier, Dispatch n. 73, 21 gennaio (1673 more veneto) 1674 S.N

ASVe (Archivio di Stato di Venezia) (1674c): Senato, Dispacci, Rettori, Corfù, b. 32, 1668-1677: Gritti, Dispatch n. 2, Corfù 10 giugno 1674 S.N.

ASVe (Archivio di Stato di Venezia) (1780-1781): Senato, Provveditori da Terra e da Mar, Provveditore Generale in Dalmazia e Albania, b. 641, September-August 1781, nn. 1-38: Paolo Boldrin, Dispatch n. 10, Zara, 30 December 1780; Paolo Boldrin, dispatch n. 16, 30 January 1781.

Basovic, R. (1973): Katalog potresa SR Crne Gore 518-1901 (Titograd), ms.

BiAnChI, C.F. (1888): Fasti di Zara religioso-politico-civili, dall'anno 1184 a.C. sino all'anno 1888 dell'era volgare, compilati dal preposito capitolare C.F. Cav. Bianchi, Zara, pp. 202.

BonITO, M. (1691): Terra tremante overo continuatione de terremoti dalla Creazione del Mondo fino al tempo presente ... (Napoli), pp. 822.

Boschi, E., G. Ferrari, P. Gasperini, E. Guidoboni, G. SMRIGLIO and G. VALENSISE (Editors) (1995): Catalogo dei Forti Terremoti in Italia dal 461 a.C. al 1980 (ING, Roma-SGA, Bologna), pp. 970.

Brunelli, V. (1911): Il «Memoriale» di Paolo de Paolo, patrizio zaratino, Il Dalmata, nn. 4-8. (1989, Atti e Memorie della Società Dalmata di Storia Patria, XVII, 101117).

Brunelli, V. (1913): Storia della città di Zara. Dai tempi più remoti sino al 1409 compilata sulle fonti e integrata da tre capitoli sugli usi e costumi, Venezia (1974, Trieste, pp. 592).

CARTER, F.W. (1972): Dubrovnik (Ragusa). A classic Citystate (Seminar Press, London and New York), pp. 686.

Chiotis, P. (1863): Seiras historikon apomnimoneumaton, Kerkyra, vol. 3.

Chronica Ragusina (15th cent.): Chronica Ragusina Junii Restii (ab origine urbis usque ad annum 1451) item Johannis Gundulae (1451-1484), Monumenta spectantia historiam Slavorum meridionalium, edited by S. Nodilo (Zagreb 1893), vol. 25, Scriptores, vol. II.

Cvijanovic, D. (1971): Potresi intenziteta $I_{0} \geq I X$ MCS do 1800 god. s epicentrom na podrucju SR Hrvatske (Zagreb), $\mathrm{ms}$.

Cvijanovic, D. (1972): Potresi intenziteta $I_{0} \geq$ VII MCS od 1801-1900 s epicentrom na podrucju SR Hrvatske (Zagreb), ms.

Cvijanovic, D. (1981): Seizmicnost podrucja SR Hrvatske, Disertacija (Sveuciliste u Zagrebu, PMF, Zagreb).

Da Mosto, A. (1937-1940): L'Archivio di Stato di Venezia. Indice generale, storico, descrittivo ed analitico (Roma), 2 vols.

De Diversis Quartigiani, F. (1440): Situs aedificiorum, politiae et laudabilium consuetudinum inclytae civitatis Ragusii, in Programma I.R. Ginnasio Superiore in Zara (18811882), edited by V. BRUNELLI, XXV, 1882, 3-36, 67 (Zara).

Di VitTorio, A. (1983): Finanze e Moneta a Ragusa nell'Età della Crisi, Napoli.

Dresdnische Geleherte Anzeigen (1756), Dresden.

EICKHOFF, E. (1991): Venezia, Vienna e i Turchi (Rusconi, Milano), pp. 520.

Evangelatou-Notara, F. (1993): Earthquakes in Byzantium (13th-15th century), historical investigation, Parousia, 24 (special issue), pp. 184 (in Greek).

Gazette de France (1780): 1 December, Paris.

GELCICH, G. (1884): Dello sviluppo civile di Ragusa, Ragusa.

Gelcich, G. (1899): La Zedda e la dinastia dei Balsidi, Spalato, pp. 335.

Gelcich, G. (1892): Delle istituzioni Sanitarie e Marittime della Repubblica di Ragusa, Trieste.

GiUstiniani, P. (1575-1576): Rerum Venetarum Historia ab urbe condita ad annum 1575, Venetia.

Gueze, R. (1970): Note sugli Archivi di Stato della Grecia (Roma), pp. 107.

Guidoboni, E. and C. Margottini (1988): The 6th April 1667 dalmatian earthquake in the Italian historical sources, in Proc. IAEA Workshop on Historical Seismicity of CentralEastern Mediterranean Region, edited by C. MARGOTTINI 
and L. SERVA, Roma, 27-29 October 1987, pp. 65-93.

HeRAK, M. (1995): Earthquake Catalog for Croatia and adjacent Regions, Archives of the Andrija Mohorovicic Geophysical Institute, Zagreb.

HoFF, K.E.A. VON (1840): Chronik der Erdbeben und VulcanAusbrüche, I. Theil (Justus Perthes, Gotha), pp. 470.

KARniK, V. (1971): Seismicity of the European Area, Part II (D. Reidel Publ. Comp., Dordrecht, Holland), pp. 218.

Kispatic, M. (1891-1892): Potresi u Hrvatskoj, Rad. Jjugosl. Akademje Znanosti i Umjetnosti, CVII, 81-164; CIX, 1-79.

KRECIC, B. (1972): Dubrovnik in the 14th and 15th Centuries: a City between East and West (University of Oklahoma Press).

LJubic, S. (1876-1880): Commissiones et relationes Venetae (1473-1571), Zagreb, 3 vols.

LJubIC, S. (1893): Listine o odnosajih izmedju juznoga Slavenstva i Mletacke Republicke, Monumenta spectantia historiam Slavorum meridionalium, edited by $\mathrm{S}$. NoDILO (Zagreb, 1883), 10 vols.

LuCCARI, G. (1605): Copioso Ristretto degli Annali di Rausa Libri quattro, Venetia (reprint, Bologna, pp. 176).

Lucio, G. (1666): De Regno Dalmatiae et Croatiae Libri sex, Amstelaedami, Apud Ioannem Blaeu, pp. 474 (+ index and maps).

Lume, L. (1977): L'archivio storico di Dubrovnik, Quaderni della Rassegna di Stato, Roma, 46.

MaLlET, R. (1853): Catalogue of recorded earthquakes from 1606 B.C. to A.D. 1850 , Brit. Ass. Rep., 1853, 1-176.

Marmora, A. (1672): Della historia di Corfù descritta da Andrea Marmora nobile corcirese libri otto, Venezia.

Mercurio Historico y Politico (1780), December, Madrid, p. 293.

MinaILovic, D.J. (1951): Catalogue des Tremblements de Terre Epiro-Albanais, Archive Séismologique de l'Institut Séismologique de Beograd, Zagreb, pp. 73.

MinaIlovic, J. (1927): Mouvements séismiques Epiro-Albanais, Union Geodesique et Geophysique Internationale, Comité Nationale du Royaume des Serbes, Croates et Slovenes, Section de Séismologie, Ser. B, Monogr. et Trav. Scient. (Beograd), 1, pp. 93.

Montandon, F. (1953): Les tremblements de terre destructeurs en Europe, Genève, pp. 195.

Morelli, C. (1942): Carta sismica dell'Albania, Reale Accademia d'Italia, Commissione Italiana di Studio per $i$ Problemi del Soccorso alle Popolazioni (Firenze), vol. X, pp. 120.

Museo Civico Correr (1666): Dispacci, Michiel Foscarini,
Cod. Cicogna 2367, 14 giugno 1665-5 luglio 1667, Venezia. Newe Zeytung (1564) n.p.

PAOLO DE PAOLI (14th-15th cent): Memoriale, in De Regno Dalmatiae et Croatiae Libri sex, edited by G. LuCIO (1666, Amstelaedami), pp. 423-438.

Papazachos, B. and K. PAPAZACHOU (1989): The Earthquakes of Greece (Ziti Publ., Thessaloniki), pp. 356.

PAPAZACHOS, B. and K. PAPAZACHOU (1997): The Earthquakes of Greece (Ziti Editions, Thessaloniki), pp. 304

PARTSCH, J. (1887): Die Insel Korfu, Eine Geographische Monographie (Gotha).

Perrey, A. (1850): Mémoires sur les tremblements de terre ressentis dans la peninsule Turco-ellenique et en Syrie, Mémoires Couronnées et Mémoires des Savant Etrangers, Academie Royale des Sciences, des Lettres et des Beaux Arts de Belgique (Bruxelles), XXIII, pp. 73.

Petter, F. (1834): Compendio Geografico della Dalmazia, con un'Appendice sul Montenegro (Zara), pp. 252.

Petter, F. (1857): Das Koenigreichen Dalmatien, Wien.

Preto, P. (1994): I Servizi Segreti di Venezia (Il Saggiatore, Milano), pp. 638.

RAZZI, S. (1595): La storia di Raugia, scritta nuovamente in tre libri, Lucca (reprint, Bologna, 1980, pp. 184).

SANudo, M. (1496-1533): Diarii, edited by R. Fulin (Venezia 1880), (reprint, Bologna, 1969, 58 vols.).

SHEBALIN, N.V. (Editor) (1974): Atlas of isoseismal maps, UNDP-UNESCO Survey of the Seismicity of the Balkan Region, Part III, Skopje, 275 maps.

SHEBALIN, N.V., V. KÁRNíK and D. HADZIEVSKI (Editors) (1974): Catalogue of earthquakes of the Balkan region, UNDP-UNESCO Survey of the Seismicity of the Balkan Region, Part I and Part II, Skopje, pp. 600.

SkURLA, S. (1871): Sv. Vlaho, Dubrovnik.

Sugar, P.F. (1977): Southeastern Europe under Ottoman Rule 1354-1804. A History of East Central Europe, vol. I, pp. 356.

Sulstarova, A. and S. Kociu (1975): The catalogue of Albanian earthquakes, Botim $i$ Qendres Sizmologjike (Tirana), pp. 223

Sulstarova, A., S. Kociu and S. Uliaj (1971): Catalogue of earthquakes in Albania, prior to 1800 , Io $\geq$ VIII; 18001970 , Io $\geq$ VI, Tirana, 1971, Mimeographed, in Map of seismic Regionalisation of the People's Republic of Albania, Tirana Seismological Station.

TRAJIC, D. (1961): Les tremblements de terre pour les années 361-1800 dans la Yougoslavie, ms.

VILLARI, L. (1904): The Republic of Ragusa. An Episode of the Turkish Conquest (London), pp. 424. 